Volume 13, No. 1, Juni 2014

ISSN 1411-514X (print)

ISSN 2355-7737 (online)

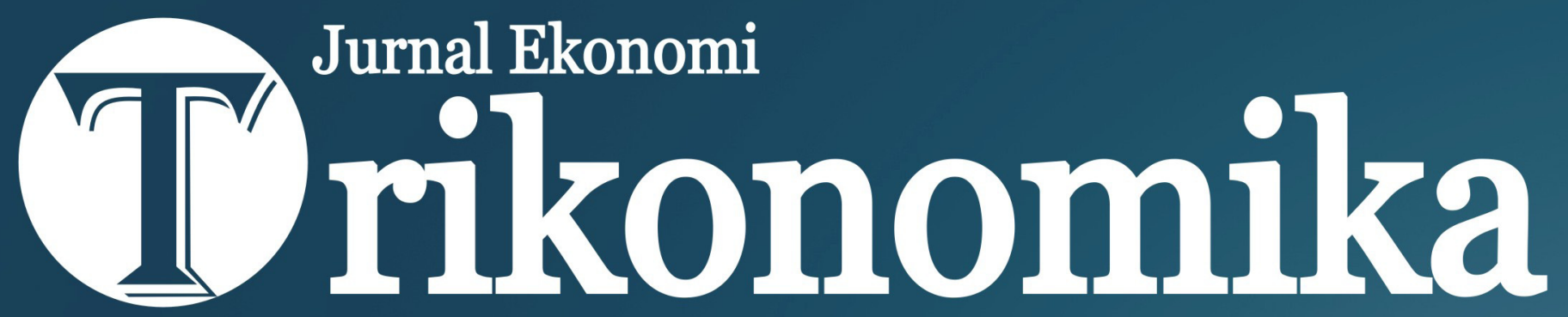




\section{DAFTAR ISI}

Trikonomika, Volume 13, No. 1, Juni 2014

Pengaruh Otonomi dan Akuntabilitas Perguruan Tinggi terhadap Kinerja Manajerial

Isnaeni Nurhayati ...

Keseimbangan Jangka Pendek dan Jangka Panjang Nilai Tukar Rupiah terhadap Dollar Amerika

Horas Djulius, Yudi Nurdiansyah

Kajian Kepemimpinan Transformasional, Komitmen Karyawan, Motivasi, Kepuasan Kerja, dan Kinerja Karyawan

Edy Saptono $21-48$

Pengaruh Kualitas Pelayanan terhadap Kepuasan Mahasiswa Program Ekstensi Fakultas Ekonomi Universitas Jambi

Yenny Yuniarti $49-61$

Determinan Profitabilitas Bank: Suatu Studi pada Bank yang Terdaftar di BEI

Jaja Suteja, Gerinata Ginting $62-77$

Faktor Determinan Minat Wirausaha Mahasiswa Fakultas Ekonomi dan Bisnis Universitas Negeri Gorontalo

Herwin Mopangga $78-90$

Pengaruh Upah dan Pengalaman Kerja terhadap Produktivitas Karyawan Kerajinan Ukiran Kabupaten Subang

Ardika Sulaeman $91-100$

Analisis Harga Saham dan Rata-Rata Abnormal Return Sebelum dan Sesudah Ex-Dividend Date (Studi pada Emiten Indeks Kompas-100)

Alvin Mulya Hidayati $101-107$

Pengaruh Manajemen Laba Akrual dengan Pendekatan Revenue Discretionary Model terhadap Kinerja Perusahaan

Sepriahangga Wahyu Windharta, Nurmala Ahmar $108-118$ 


\title{
Kajian Kepemimpinan Transformasional, Komitmen Karyawan, Motivasi, Kepuasan Kerja, dan Kinerja Karyawan
}

\author{
Edy Saptono \\ Pabandya Faskon Ditmin Sesko TNI \\ Jl. RAA. Martanegara No. 11 Bandung \\ E-Mail: edysptn@yahoo.com
}

\begin{abstract}
The research was conducted at BUMN Company of Defence Industry in West Java consists of the District and the city of PT Pindad, PT Dahana, PT Dirgantara Indonesia, PT LEN and PT Inti. The purpose of this study to determine, assess and analyze descriptive and verification of transformational leadership, employee commitment, motivation, job satisfaction and employee performance. Sample of this study using sampling technique cluster proporsional stratified random sampling. Methods of data collection using questionnaries. This research method using descriptive and verivicative with analysis technique of Structural Equation Modelling (SEM). Results from descriptive studies prove that transformational leadership rating of effective categories, employee commitment rating of strong categories, motivation rating of high categories, job satisfaction rating of satisfied categories and employee performance rating of high categories, but there are still some emploies who rate not good perception. The results of the verivication studies prove that transformational Leadership, employee commitment and motivation has a positive and significant impact on the job satisfaction either partially or simultaneously and job satisfaction has a positive and significant impact on employee performance.
\end{abstract}

Keywords: transformational leadership, employee commitment, motivation, job satisfaction and employee performance.

\begin{abstract}
ABSTRAK
Penelitian ini dilakukan di perusahaan BUMN Industri Pertahanan Jawa Barat yang terdiri dari PT Pindad, PT Dahana, PT Dirgantara Indonesia, PT LEN, dan PT Inti. Tujuan penelitian ini untuk mengetahui, mengkaji dan menganalisis secara deskriptif dan verifikatif kepemimpinan transformasional, komitmen karyawan, motivasi, kepuasan kerja dan kinerja karyawan. Sampel penelitian menggunakan teknik cluster proporsional stratified random sampling. Metode pengumpulan data menggunakan metode angket atau kuesioner. Metode penelitian menggunakan metode deskriptif dan verivikatif dengan teknik analisis Structural Equation Modelling (SEM). Hasil penelitian secara deskriptif membuktikan bahwa kepemimpinan transformasional dipersepsikan cukup kuat sampai ke kuat, komitmen karyawan dipersepsikan cukup tinggi sampai ke sangat tinggi dan motivasi karyawan dipersepsikan cukup tinggi sampai ke sangat tinggi, kepuasan kerja dipersepsikan cukup puas sampai ke sangat puas dan kinerja karyawan dipersepsikan cukup tinggi sampai ke sangat tinggi. Hasil penelitian secara verifikatif membuktikan bahwa kepemimpinan transformasional, komitmen karyawan, dan motivasi secara simultan maupun parsial berpengaruh positif dan signifikan terhadap kepuasan kerja serta kepuasan kerja berpengaruh positif dan signifikan terhadap kinerja karyawan.
\end{abstract}

Kata Kunci:kepemimpinan transformasional, komitmen karyawan, motivasi, kepuasan kerja dan kinerja karyawan. 


\section{PENDAHULUAN}

Dalam pasal 33 UUD 1945, Indonesia menganut sistem ekonomi nasional yang didasarkan pada demokrasi ekonomi dengan memanfaatkan dan mengelola sumber daya yang ada sehingga tercipta perekonomian nasional yang baik. Pelaku ekonomi yang diharapkan untuk mengelola sumber daya tersebut adalah BUMN , BUMD, Koperasi, dan Swasta.

Pasca-reformasi, pengelolaan BUMN diatur dalam Ketetapan MPR Nomor IV/MPR/1999 tentang Penataan BUMN secara efisien, transparan, dan profesional. Untuk melaksanakan Ketetapan MPR tersebut, diterbitkan UURI Nomor 19 Tahun 2003 tentang Badan Usaha Milik Negara (BUMN). BUMN adalah badan usaha yang seluruh atau sebagian besar modalnya dimiliki oleh negara melalui penyertaan secara langsung yang berasal dari kekayaan negara yang dipisahkan. BUMN terdiri dari tiga bagian, yaitu: Perusahaan Perseroan (Persero), Perusahaan Perseroan Terbuka (Persero Terbuka) dan Perusahaan Umum (Perum).

Untuk mewujudkan visi dan misinya, maka Perusahaan BUMN dalam melakukan usahanya dibagi dalam delapan sektor usaha. Berdasarkan data empirik dari perusahaan BUMN maka terlihat bahwa kinerja keuangan perusahaan BUMN sektor Industri Pertahanan terlihat paling kecil dan fluktuatif, seperti terlihat dalam Tabel 1.

Tabel 1. Kinerja Keuangan (Laba Bersih)

Perusahaan BUMN Periode Tahun 2008 s/d 2011

(Milyar Rupiah)

\begin{tabular}{crrrrr}
\hline No. & Sektor Usaha BUMN & $\mathbf{2 0 0 8}$ & $\mathbf{2 0 0 9}$ & $\mathbf{2 0 1 0}$ & $\mathbf{2 0 1 1}$ \\
\hline 1 & Pertanian & 56 & 154 & 219 & 362 \\
2 & $\begin{array}{l}\text { Pertambangan } \\
\text { dan Energi }\end{array}$ & 3776 & 9987 & 19327 & 18315 \\
3 & Telekomunikasi & 12854 & 10674 & 11344 & 11544 \\
4 & Konstruksi & 571 & 1056 & 1684 & 2481 \\
5 & Sarana Prasarana & & & & \\
& Angkutan & 827 & 1557 & 2441 & 1896 \\
6 & Asuransi & 2607 & 3292 & 5506 & 5591 \\
7 & Perbankan & 10763 & 13166 & 17438 & 25708 \\
8 & Industri Pertahanan & 37 & 61 & 121 & 94 \\
\hline
\end{tabular}

Sumber: Laporan Perusahaan BUMN, diolah oleh peneliti.
Dalam rangka pemberdayaan industri pertahanan nasional diterbitkan UU Nomor 16 Tahun 2012 tentang Industri Pertahanan. Sebelum undang-undang tersebut diratifikasi oleh DPR dan pemerintah, maka pemerintah mengeluarkan Perpres Nomor 42 Tahun 2010 tentang Komite Kebijakan Industri Pertahanan (KKIP). Tugas KKIP yaitu:(a) merumuskan kebijakan nasional yang bersifat strategis di bidang industri pertahanan, (b) mengkoordinasikan pelaksanaan dan pengendalian kebijakan nasional industri pertahanan. Dalam Perpres tersebut menjelaskan tentang peran, visi dan misi Badan Usaha Milik Negara Industri Pertahanan (BUMNIP). Visi utama BUMNIP adalah menjadikan industri pertahanan dalam negeri berdaya saing tinggi dan mampu memenuhi kebutuhan alutsista, sarana pertahanan dan peralatan keamanan dalam negeri. Misi utama BUMNIP adalah memenuhi kebutuhan dasar TNI (Matra Darat, Laut, dan Udara), menguasai teknologi dan mempunyai akar industri dalam negeri, mengembangkan sumber daya manusia yang mumpuni dan kreatif. Perusahaan BUMNIP yang mendapatkan prioritas dalam kebijakan revitalisasi industri pertahanan adalah PT Pindad, PT Dahana, PT Inti, PT LEN Industri, PT DI, dan PT PAL.

Perusahaan BUMNIP dalam beberapa tahun terakhir mempunyai masalah terkait dengan belum optimalnya kinerja perusahaan, Berdasarkan Gambar 1. maka salah satu penyebab dari fluktuasinya pendapatan usaha perusahaan BUMNIP adalah kinerja karyawan perusahaan BUMNIP belum optimal.

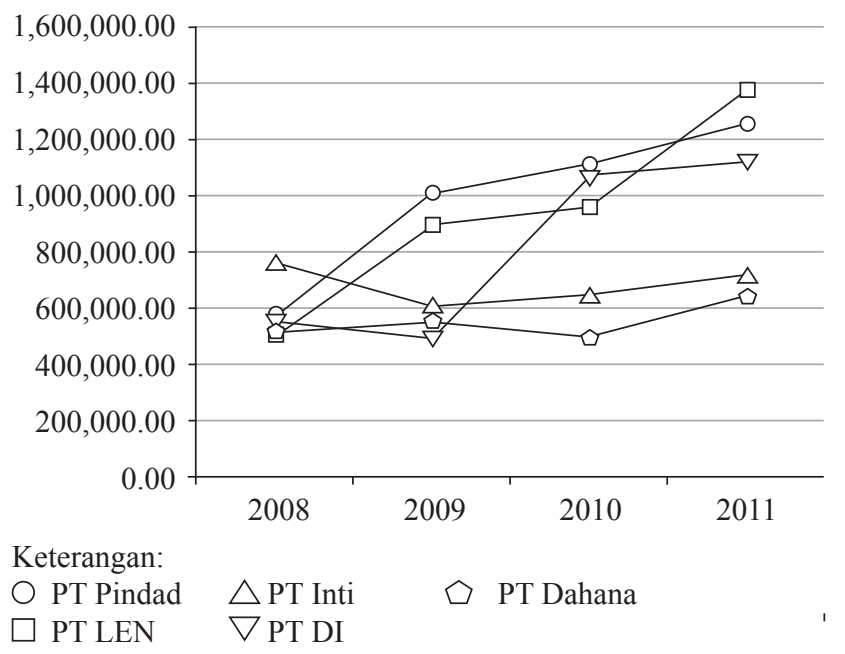

Sumber: Laporan Perusahaan BUMN, diolah oleh peneliti. Gambar 1. Pendapatan Usaha Perusahaan BUMNIP Tahun 2008 s/d 2011 
Salah satu penyebab belum optimalnya kinerja karyawan tersebut adalah ditandai dengan masih terjadinya fluktuasi produktivitas karyawan dan belum optimalnya nilai sasaran kinerja individu. Berdasarkan data empiris bahwa produktivitas kerja karyawan perusahaan BUMNIP selama periode waktu tahun 2008 s/d 2011 sangat variatif, seperti terlihat dalam Tabel 2.

Tabel 2. Produktivitas Kerja Karyawan

Perusahaan BUMNIP Periode Tahun 2008 s/d 2011

\begin{tabular}{|c|c|c|c|c|}
\hline Peru & $\begin{array}{c}2008 \\
\text { (juta/orang) }\end{array}$ & $\begin{array}{c}2009 \\
\text { (juta/orang) }\end{array}$ & $\begin{array}{c}2010 \\
\text { (juta/orang) }\end{array}$ & $\begin{array}{c}2011 \\
\text { (juta/orang) }\end{array}$ \\
\hline$d$ & Rp. 200,61 & Rp. 400,95 & Rp. $\quad 380,18$ & Rp. $\quad 544,69$ \\
\hline Dahana & Rp. 894,93 & Rp. 978,98 & Rp. 907,92 & Rp. $1.201,34$ \\
\hline$\Gamma \mathrm{DI}$ & Rp. 195,26 & Rp. 178,50 & Rp. 391,88 & Rp. $\quad 410,13$ \\
\hline PT Inti & Rp. 1.045, & Rp. 861,97 & Rp. 933,45 & Rp. 1.0 \\
\hline PT LEN & Rp. $1.020,80$ & Rp. $1.850,18$ & Rp. $2.063,89$ & Rp. $3.068,79$ \\
\hline
\end{tabular}

Sumber: Laporan Perusahaan BUMNIP, diolah oleh peneliti.

Sesuai data empiris tentang penilaian kinerja karyawan yang didasarkan pada nilai Sasaran Kerja Individu (SKI) bahwa nilai rata-rata SKI karyawan perusahaan BUMNIP periode tahun 2008-2011 menunjukkan angka yang variatif seperti terlihat pada Tabel 3 .

Tabel 3. Daftar Nilai SKI Karyawan Perusahaan BUMNIP Periode Tahun 2008 s/d 2011

\begin{tabular}{lcccc}
\hline \multirow{2}{*}{ Perusahaan Nilai SKI } \\
\cline { 2 - 5 } & $\mathbf{2 0 0 8}$ & $\mathbf{2 0 0 9}$ & $\mathbf{2 0 1 0}$ & $\mathbf{2 0 1 1}$ \\
\hline PT Pindad & 76,72 & 76,24 & 75,78 & 76,85 \\
PT Dahana & 86,34 & 87,21 & 86,90 & 87,45 \\
PT DI & 88,10 & - & - & - \\
PT Inti & 75,99 & 73,17 & 78,20 & 71,29 \\
PT LEN & 85,75 & 87,88 & 86,69 & 88,20 \\
\hline
\end{tabular}

Sumber: Laporan Perusahaan BUMNIP, diolah oleh peneliti.

Fenomena yang terjadi di perusahaan BUMNIP mengindikasikan bahwa karyawan yang bekerja di perusahaan tersebut belum melaksanakan kerja secara optimal, kurang disiplin, dan belum sepenuhnya mematuhi peraturan.

Hasil tersebut sesuai dengan hasil penelitian yang dilakukan oleh Saydam (2005) bahwa karyawan yang melakukan pekerjaan tanpa kedisiplinan akan berdampak negatif bagi perusahaan yang pada akhirnya akan mempengaruhi kinerja karyawan.

Agar kinerja perusahaan menunjukkan trend kenaikan positif, maka para karyawan dituntut untuk dapat melaksanakan tugas secara profesional yang dibebankan kepadanya sehingga karyawan tersebut mempunyai pola pikir yang baik,selalu bekerja keras dengan waktu yang ditargetkan, disiplin, jujur dan memiliki loyalitas tinggi serta penuh dedikasi untuk keberhasilan tugas dan pekerjaan yang diembannya.

Bila dikaitkan dengan data empirik kinerja karyawan perusahaan BUMNIP yang belum optimal, maka diindikasikan bahwa karyawan yang bekerja di perusahaan BUMNIP tersebut dalam bekerja belum mendapatkan kepuasan kerja seperti yang diharapkan.

Berdasarkan fenomena dilapangan dan hasil wawancara dengan Kadiv MSDM BUMNIP di Jawa Barat, para karyawan menyuarakan ketidakpuasan kepada pihak manajemen perusahaan terkait sistem reward dan punishment dengan melakukan diskusi dengan para pimpinan dan ada sebagian karyawan melakukan aksi demo untuk menyuarakan pendapat (Voice) karyawan tentang ketidakpuasannya pada perusahaan.

Kinerja akan meningkat apabila kepuasan karyawan terpenuhi, seperti hasil penelitian Morison (2008), "Karyawan akan memberikan yang terbaik apabila mereka juga mendapatkan terbaik dari perusahaan". Menurut Ostroff (2003) menjelaskan bahwa Kepuasan kerja berpengaruh langsung terhadap peningkatan kinerja dimana karyawan yang lebih terpuaskan cenderung lebih efektif dari pada perusahaan-perusahaan dengan karyawan yang kurang terpuaskan.

Menurut beberapa peneliti dan teori, salah satu cara untuk meningkatkan kinerja karyawan adalah meningkatkan kepuasan kerja para karyawan, sedangkan faktor-faktor yang dapat meningkatkan kepuasan kerja karyawan diantaranya adalah bagaimana penerapan kepemimpinan dilaksanakan di suatu perusahaan. Permasalahan kepemimpinan yang biasanya muncul di perusahaan BUMNIP di Jawa Barat yaitu kukuhnya pimpinan dalam menerapkan kebiasaan lama dan bukan karena pengaruh dinamika pasar yang berlangsung saat ini, tetapi para pemimpin atau manajer seringkali terpaku dengan perilaku yang dibawanya, kurang mengantisipasi kegiatan operasional dalam upaya menyelaraskan dengan perubahan yang sangat cepat. 
Dalam situasi dan kondisi lingkungan strategis baik regional maupun global Kepemimpinan transformasional mampu mengubah situasi dan lingkungan dengan memberikan motivasi dan melalui komunikasi yang inspirasional terhadap para karyawan sehingga lingkungan kerja dan bisnis menjadi kondusif untuk berkinerja tinggi. Dalam teori sumber daya manusia disebutkan bahwa kepemimpinan yang cocok untuk organisasi atau perusahaan yang sedang melakukan transformasi dan menginginkan kinerja tinggi yaitu kepemimpinan transformasional. Pemimpin yang berkarakter transformasional mampu mempengaruhi orang lain untuk berubah dan mengubah situasi dan lingkungan dengan memberikan inspirasi kepada orang lain untuk mengubah keadaan transedental menuju kondisi yang lebih baik.

Selain kepemimpinan transformasional, komitmen karyawan dapat mempengaruhi kepuasan kerja karyawan. Komitmen karyawan merupakan suatu kondisi yang dirasakan oleh karyawan sehingga dapat menimbulkan perilaku positif yang kuat terhadap organisasi kerja yang dimilikinya.

Menurut Hackett dan Guinon (1985) karyawan yang mempunyai komitmen terhadap organisasi yang tinggi akan berdampak pada karyawan tersebut, yaitu ia lebih puas dengan pekerjaan dan tingkat absensinya menurun. Truckenbrodt (2000) menyatakan kuat lemahnya komitmen karyawan pada organisasi dapat dilihat dari kinerja organisasi, tingkat rendahnya turn over dan tinggi rendahnya tingkat absensi kerja karyawan. Hal serupa disampaikan oleh Farrel dan James (1984) bahwa karyawan yang memilikikomitmen rendah akan berdampak pada turn over, tingginya absensi dan meningkatnya kelambanan kerja.

Tabel 4. Rekapitulasi Absensi/Ketidakhadiran Karyawan Perusahaan BUMNIP Tahun 2009 s/d 2011 (dalam \%)

\begin{tabular}{lccc}
\hline \multicolumn{1}{c}{ Perusahaan } & $\mathbf{2 0 0 9}$ & $\mathbf{2 0 1 0}$ & $\mathbf{2 0 1 1}$ \\
\hline PT Pindad & $14,88 \%$ & $11,16 \%$ & $9,40 \%$ \\
PT Dahana & $10,39 \%$ & $12,20 \%$ & $13,91 \%$ \\
PT DI & $9,91 \%$ & $11,22 \%$ & $13,30 \%$ \\
PT Inti & $10,40 \%$ & $11,84 \%$ & $8,16 \%$ \\
PT LEN & $10,90 \%$ & $10,46 \%$ & $10,10 \%$ \\
\hline
\end{tabular}

Sumber: Laporan Perusahaan BUMNIP, diolah oleh peneliti.

Berdasarkan data empirik dari laporan pihak manajemen perusahaan BUMNIP di Jawa Barat berupa data tingkat absensi atau ketidakhadiran karyawan perusahaan BUMNIP yang menunjukkan prosentase yang cukup tinggi dan sifatnya fluktuatif dalam periode waktu tertentu, seperti terlihat pada Tabel 4.

Selain kepemimpinan transformasional dan komitmen karyawan yang mempengaruhi kepuasan kerja, juga yang tidak kalah pentingnya adalah motivasi. Motivasi sebagai pendorong timbulnya semangat atau dorongan kerja. Kuat dan lemahnya motivasi seseorang mempunyai pengaruh terhadap besar kecilnya prestasi yang diraih. Motivasi sangat penting bagi tinggi rendahnya produktivitas perusahaan. Jika para karyawan memiliki motivasi rendah untuk bekerja, baik secara personal maupun bekerja sama dengan rekannya bagi kepentingan perusahaan, maka tujuan yang telah ditetapkan tidak akan tercapai. Sebaliknya jika para karyawan memiliki motivasi besar maka hal tersebut dapat menjadi jaminan atas keberhasilan perusahaan dalam mencapai tujuan.

Problem yang dihadapi oleh perusahaan BUMNIP adalah menurunnya motivasi kerja karyawan. Hal ini dikarenakan oleh semakin meningkatnya volume kerja setiap tahun sedangkan jumlah karyawan yang tersedia terbatas sehingga hal ini memicu tingkat kemalasan karyawan. Dengan tingkat kemalasan yang tinggi terjadilah penumpukan pekerjaan sehingga mengakibatkan pekerjaan tidak dapat diselesaikan tepat pada waktu yang telah ditetapkan.

Berdasarkan laporan dari pihak manajemen perusahaan BUMNIP, bahwa jam kerja hilang cukup tinggi, seperti terlihat pada Tabel 5.

Tabel 5. Rekapitulasi Jam Hilang Kerja Karyawan Perusahaan BUMN Industri Pertahanan Periode Tahun 2009-2011 (dalam Jam)

\begin{tabular}{lrrr}
\hline Perusahaan & $\mathbf{2 0 0 9}$ (Jam) & $\mathbf{2 0 1 0}$ (Jam) & $\mathbf{2 0 1 1}$ (Jam) \\
\hline PT Pindad & 40.940 & 79.335 & 37.587 \\
PT Dahana & 10.380 & 11.910 & 12.564 \\
PT DI & 258.531 & 320.434 & 400.735 \\
PT Inti & 41.640 & 42.718 & 40.108 \\
PT LEN & 41.080 & 38.636 & 34.399 \\
\hline
\end{tabular}

Sumber: Laporan Perusahaan BUMNIP, diolah oleh peneliti.

Hal ini mengindikasikan motivasi karyawan dalam menyelesaikan pekerjaan yang menjadi tanggung jawabnya masih belum optimal. 
Berdasarkan hasil penelitian yang dilakukan oleh Jones (2003), "Para pekerja yang kurang termotivasi dalam bekerja maka mereka akan memulai reaksinya dengan tindakan-tindakan ringan, seperti datang terlambat sebelum beralih ke tindakan yang lebih berat yaitu absen dan pada akhirnya keluar dari perusahaan".

Fenomena diatas menunjukkan bahwa kinerja karyawan di perusahaan BUMNIP di Jawa Barat relatif masih belum optimal, begitu juga kepuasan kerja yang dirasakan oleh para karyawan belum sesuai harapan, serta komitmen karyawan terhadap organisasi pada taraf belum kuat, kecenderungan motivasi masih belum tinggi dan kepemimpinan transformasional belum efektif dilaksanakan. Berdasarkan uraian tersebut, maka penulis tertarik untuk melakukan penelitian lebih mendalam tentang masalah tersebut.

\section{METODE}

Metode yang digunakan dalam penelitian ini adalah metode descriptive dan explanatory survey, sedangkan tipe hubungan antara variabel yang digunakan dalam penelitian ini adalah causalitas yaitu variabel independen atau variabel bebas mempengaruhi variabel dependen/variabel terikat. Fenomena dalam objek penelitian yaitu karyawan perusahaan BUMN Industri Pertahanan di Jawa Barat. Penelitian ini berdasarkan deskripsi dari suatu keadaan dan fenomena yang terjadi pada waktu antara tahun 2008 sampai dengan 2011.

Analisa deskriptif akan dijelaskan tentang variabel-variabel independen maupun variabelvariabel dependen yang menjadi landasan teori dalam penelitian yang memuat teori-teori dari variabel yang diteliti. Analisa verifikatif untuk menguji kebenaran suatu hipotesis yang dilaksanakan melalui pengumpulan data di lapangan tentang variabelvariabel yang akan diteliti. Dalam penelitian ini, analisa verifikatif yang digunakan adalah statistik Structural Equation Model (SEM).

\section{Tempat Penelitian}

Lokasi BUMNIP tersebar di beberapa wilayah di Indonesia, namun dalam penelitian ini lokasi difokuskan di perusahaan BUMNIP di Jawa Barat. Adapun perusahaan dan lokasi BUMNIP di Jawa Barat, yaitu: PT Pindad, PT Dirgantara Indonesia,
PT Dahana, PT Industri Telekomunikasi Indonesia, dan PT LEN Industri.

\section{Definisi dan Operasionalisasi Variabel}

Variabel yang akan diteliti dalam penelitian ini terdiri dari 5 (lima) variabel, yaitu variabel independen meliputi variabel kepemimpinan transformasional (X1) dengan dimensi pengaruh ideal, motivasi inspirasional, dan stimulasi intelektual; variabel komitmen karyawan (X2) dengan dimensi komitmen afektif, komitmen berkelanjutan dan komitmen normatif; variabel motivasi (X3) dengan dimensi kebutuhan berprestasi, kebutuhan berafiliasi, kebutuhan berkuasa, dan variabel kepuasan kerja (Y) sebagai variabel intervening dengan dimensi faktor psikologi, faktor finansial, faktor fisik, faktor sosial, serta variabel kinerja karyawan $(Z)$ sebagai variabel dependen dengan dimensi kemampuan, efektifitas dan efisiensi, otoritas, disiplin, dan inisiatif. Definisi serta operasionalisasi variabel-variabel penelitian dapat dilihat pada Tabel 6. dan Tabel 7.

\section{Sumber Data}

Sumber data yang digunakan dalam penelitian ini merupakan data primer dan data sekunder. Secara khusus, data primer dikumpulkan oleh peneliti berdasarkan kuesioner yang dibagikan kepada responden untuk menjawab pernyataan maupun pertanyaan penelitian. Data sekunder dalam penelitian ini dikumpulkan dari perusahaan yang meliputi literatur, dokumentasi atau laporan-laporan yang terkait dengan objek penelitian dan pedoman yang dikeluarkan oleh masing-masing perusahaan BUMNIP di Jawa Barat.

\section{Teknik Pengumpulan Data dan Informasi}

Penelitian tentang pengaruh kepemimpinan transformasional, komitmen organisasi dan motivasi terhadap kepuasan kerja serta implikasinya terhadap kinerja karyawan diperlukan data primer dan data sekunder. Dalam penentuan data menggunakan teknik sampling yaitu Proportional cluster stratified random sampling.

\section{Populasi dan Sampel Penelitian}

Jumlah populasi dalam penelitian ini sebanyak 5.982 orang yang terdiri dari karyawan perusahaan BUMNIP yang dikelompokkan berdasarkan cluster perusahaan maupun strata (level) kepangkatan. 
Tabel 6. Definisi Variabel Penelitian

\begin{tabular}{|c|c|c|}
\hline No. & Variabel & Definisi \\
\hline 1 & $\begin{array}{l}\text { Kepemimpinan } \\
\text { Transformasional } \\
\text { (X1) }\end{array}$ & $\begin{array}{l}\text { Kepemimpinan trans-transformasional adalah kepemimpinan yang mempunyai kemampuan untuk } \\
\text { mengubah status quo dengan memberikan values dan keinginan bawahan guna mencapai tujuan yang } \\
\text { lebih tinggi (Stone et al., 2004). }\end{array}$ \\
\hline 2 & $\begin{array}{l}\text { Komitmen } \\
\text { Karyawan (X2) }\end{array}$ & $\begin{array}{l}\text { Komitmen karyawan adalah suatu konstruk psikologis yg merupakan karakteristik hubungan anggota } \\
\text { organisasi dengan organisasinya yang berdampak terhadap kepu tusan individu untuk tetap melanjutkan } \\
\text { keanggotaannya dalam organisasi atau derajat dimana karyawan percaya dan mau menerima tujuan } \\
\text { organisasi serta akan tetap tinggal atau tidak meninggalkan organisasi (Meyer dan Allen, 2007). }\end{array}$ \\
\hline 3 & Motivasi (X3) & $\begin{array}{l}\text { Motivasi adalah cadangan energi potensial yang dimiliki seseorang untuk melakukan suatu usaha atau } \\
\text { kerja berprestasi lebih baik daripada prestasi orang lain (Robbins dan Judge, 2009) }\end{array}$ \\
\hline 4 & $\begin{array}{l}\text { Kepuasan Kerja } \\
\text { (Y) }\end{array}$ & $\begin{array}{l}\text { Kepuasan kerja adalah suatu sikap yang umum sebagai hasil dari berbagai sifat khusus individu } \\
\text { terhadap faktor kerja, karakteristik individu dan hubungan sosial individu diluar pekerjaan itu sendiri, } \\
\text { atau sikap emosional yang menyenangkan dan mencintai pekerjaan, sehingga sikap ini dicerminkan } \\
\text { oleh moral kerja, kedisiplinan dan prestasi kerja yang dinikmati di dalam pekerjaan maupun di luar } \\
\text { pekerjaan (Robbins dan Judge, 2009) }\end{array}$ \\
\hline 5 & $\begin{array}{l}\text { Kinerja Karyawan } \\
(Z)\end{array}$ & $\begin{array}{l}\text { Kinerja karyawan adalah hasil kerja secara kualitas dan kuantitas yang dicapai seorang karyawan dalam } \\
\text { melaksanakan tugas sesuai dengan tang gung jawab yang diberikannya atau kinerja merupakan sistem } \\
\text { yang digunakan untuk menilai dan mengetahui apakah seorang karyawan telah melaksanakan } \\
\text { pekerjaannya secara keseluruhan, atau merupakan perpaduan dari hasil kerja (apa yang harus dicapai } \\
\text { seseorang) dan kompetensi (bagaimana seseorang mencapainya. (Mathis dan Jackson, 2008). }\end{array}$ \\
\hline
\end{tabular}

Tabel 7. Operasionalisasi Variabel Penelitian

\begin{tabular}{|c|c|c|c|}
\hline Variabel & Dimensi & Indikator & Skala \\
\hline \multirow[t]{4}{*}{$\begin{array}{l}\text { Kepemimpinan } \\
\text { Transformasional (X1) }\end{array}$} & $\begin{array}{l}\text { Pengaruh ideal } \\
\text { (Idealized Influence) } \\
\text { (X1.1) }\end{array}$ & $\begin{array}{l}\text { - } \text { Visi, misi, dan progja jelas. } \\
\text { - Memiliki karisma, arif, dan bijaksana. } \\
\text { - Memiliki integritas. } \\
\text { - Memiliki kemampuan berdayakan bawahan. } \\
\text { - Menjadi suri tauladan bawahan. } \\
\text { - Kemampuan membangun rasa percaya bawahan. }\end{array}$ & Ordinal \\
\hline & $\begin{array}{l}\text { Motivasi } \\
\text { Inspirasional } \\
\text { (Inspirational } \\
\text { motivation) (X1.2) }\end{array}$ & $\begin{array}{l}\text { - Memiliki standar kerja tinggi. } \\
\text { - Kemampuan dorong bawahan untuk mencapai standar kerja tinggi. } \\
\text { - Kemampuan memotivasi bawahan. } \\
\text { - Kemampuan memberi inspirasi dan motivasi bawahan untuk } \\
\text { tingkatkan karir. } \\
\text { - Kemampuan mengkomunisasikan tujuan. } \\
\text { - Kemampuan bangkitkan semangat kerja. }\end{array}$ & Ordinal \\
\hline & $\begin{array}{l}\text { Stimulasi } \\
\text { Intelektual } \\
\text { (Intellectual } \\
\text { stimulation) (X1.3) }\end{array}$ & $\begin{array}{l}\text { - Mendorong bawahan kreatif. } \\
\text { - Mendorong bawahan selesaikan masalah dengan rasional. } \\
\text { - Menghargai ide-ide bawahan. } \\
\text { - Menyukai tantangan kerja dan perubahan. } \\
\text { - Mengikuti perkembangan informasi dan teknologi. } \\
\text { - Mendorong karyawan belajar. }\end{array}$ & Ordinal \\
\hline & $\begin{array}{l}\text { Perhatian Individu } \\
\text { (Individual } \\
\text { consideration) } \\
\text { (X1.4) }\end{array}$ & $\begin{array}{l}\text { - Memperhatikan bawahan untuk berprestasi dan berkembang. } \\
\text { - Menghargai dan menerima perbedaan keinginan bawahan. } \\
\text { - Membantu pemecahan masalah bawahan. } \\
\text { - } \text { Berinteraksi aktif dengan bawahan. } \\
\text { - Memperhatikan bawahan yg berprestasi. } \\
\text { - Melakukan komunikasi individual. }\end{array}$ & Ordinal \\
\hline
\end{tabular}




\begin{tabular}{|c|c|c|c|}
\hline \multirow[t]{3}{*}{$\begin{array}{l}\text { Komitmen Karyawan } \\
\text { (X2) }\end{array}$} & $\begin{array}{l}\text { Komitmen } \\
\text { Afektif (Affective } \\
\text { Commitment) (X2.1) }\end{array}$ & $\begin{array}{l}\text { - Memiliki kemauan kerja secara ekstra. } \\
\text { - Tingkat kebanggaan terhadap perusahaan. } \\
\text { - Memiliki perasaan bangga terhadap tugas. } \\
\text { - Kepedulian Pegawai terhadap nasib perusahaan. } \\
\text { - Memiliki ikatan emosional dengan perusahaan. }\end{array}$ & Ordinal \\
\hline & $\begin{array}{l}\text { Komitmen } \\
\text { Berkelanjutan } \\
\text { (Continutance } \\
\text { Commitment) (X2.2) }\end{array}$ & $\begin{array}{l}\text { - Loyal dan tetap ingin di perusahaan. } \\
\text { - Merasa sulit mencari ganti perusahaan. } \\
\text { - Menyadari sangat membutuhkan perusahaan. } \\
\text { - Merasa rugi jika meninggalkan perusahaan. } \\
\text { - Manfaat bekerja yang diperoleh dalam jangka waktu lama. }\end{array}$ & Ordinal \\
\hline & $\begin{array}{l}\text { Komitmen } \\
\text { Normatif } \\
\text { (Normative } \\
\text { Commitment) (X2.3) }\end{array}$ & $\begin{array}{l}\text { - Menerima semua tugas. } \\
\text { - Menerima Tujuan dan nilai-nilai perusahaan. } \\
\text { - Mengutamakan kepentingan perusahaan. } \\
\text { - Memiliki niat dan wajib tetap bekerja di perusahaan. } \\
\text { - Sesuaikan sikap dan perilaku dengan strategi perusahaan. }\end{array}$ & Ordinal \\
\hline \multirow[t]{3}{*}{ Motivasi (X3) } & $\begin{array}{l}\text { Kebutuhan } \\
\text { berprestasi } \\
\text { (Need for } \\
\text { Achievement) (X3.1) }\end{array}$ & $\begin{array}{l}\text { - Berusaha mencapai prestasi tinggi. } \\
\text { - Berkemauan berprestasi. } \\
\text { - Keinginan untuk mendapat umpan balik. } \\
\text { - Bersedia menerima resiko dan tanggung jawab. }\end{array}$ & Ordinal \\
\hline & $\begin{array}{l}\text { Kebutuhan } \\
\text { berafiliasi } \\
\text { (Need for affiliation) } \\
\text { (X3.2) }\end{array}$ & $\begin{array}{l}\text { - Memperhatikan hubungan pribadi. } \\
\text { - Mempunyai hubungan erat, kooperatif. } \\
\text { - Kerjasama dengan rekan kerja. } \\
\text { - } \text { Bempunyai sifat terbuka menerima saran. } \\
\text { - Bersikap Komunikatif. } \\
\text { - Tidak ingin konflik dengan karyawan lain. }\end{array}$ & Ordinal \\
\hline & $\begin{array}{l}\text { Kebutuhan } \\
\text { Kekuasaan } \\
\text { (Need for Power) } \\
\text { (X3.3) }\end{array}$ & $\begin{array}{l}\text { - Mempunyai ide-ide untuk memimpin. } \\
\text { - } \text { Aktif dalam tentukan arah pekerjaan. } \\
\text { - } \text { Keinginan kendalikan dan pengaruhi karyawan lain. } \\
\text { - Mempunyai karakter kuat untuk memimpin. } \\
\text { - Melakukan aktualisasi diri agar diikuti karyawan lain. }\end{array}$ & Ordinal \\
\hline \multirow[t]{4}{*}{ Kepuasan Kerja (Y) } & $\begin{array}{l}\text { Faktor Psikologi } \\
\text { (Y1.1) }\end{array}$ & $\begin{array}{l}\text { - } \text { Minat terhadap pekerjaan. } \\
\text { - } \text { Bakat dan ketrampilan. } \\
\text { - } \text { Sikap terhadap kerja. } \\
\text { - } \text { Ketentraman dan ketenangan dalam bekerja. }\end{array}$ & Ordinal \\
\hline & $\begin{array}{l}\text { Faktor Finansial } \\
(\mathrm{Y} 1.2)\end{array}$ & $\begin{array}{l}\text { - Sistem dan besarnya gaji. } \\
\text { - Jaminan sosial. } \\
\text { - Tunjangan. } \\
\text { - Fasilitas kesehatan dan rumah. }\end{array}$ & Ordinal \\
\hline & Faktor Fisik (Y1.3) & $\begin{array}{l}\text { - Peralatan kerja. } \\
\text { - Sarana dan prasarana kerja. } \\
\text { - Keadaan ruangan kerja. } \\
\text { - Pengaturan suhu, penerangan dan pertukaran udara di ruang kerja. } \\
\text { - Kondisi kesehatan karyawan. } \\
\text { - Faktor keamanan dan keselamatan. }\end{array}$ & Ordinal \\
\hline & Faktor Sosial (Y1.4) & $\begin{array}{l}\text { - Interaksi dengan karyawan satu pekerjaan. } \\
\text { - Interaksi karyawan dengan atasan. } \\
\text { - Interaksi dengan karyawan beda pekerjaan. }\end{array}$ & Ordinal \\
\hline
\end{tabular}




\begin{tabular}{|c|c|c|c|}
\hline \multirow[t]{5}{*}{ Kinerja Karyawan (Z) } & $\begin{array}{l}\text { Kemampuan } \\
\text { (Ability) (Z1.1) }\end{array}$ & $\begin{array}{l}\text { - Kecakapan kerja. } \\
\text { - Kesungguhan dalam bekerja. } \\
\text { - Kemampuan mengambil keputusan. } \\
\text { - Kemampuan menentukan prioritas. } \\
\text { - Kemampuan bekerja sama. }\end{array}$ & Ordinal \\
\hline & $\begin{array}{l}\text { Efektifitas dan } \\
\text { efisiensi (Effectivity } \\
\text { and efficiency) } \\
\text { (Z1.2) }\end{array}$ & $\begin{array}{l}\text { - } \text { Daya guna dan hasil guna. } \\
\text { - } \quad \text { Ketepatan waktu menyelesaikan tugas. } \\
\text { - } \quad \text { Hasil kerja berdampak pada perusahaan. } \\
\text { - Gunakan material sesuai kebutuhan. }\end{array}$ & Ordinal \\
\hline & $\begin{array}{l}\text { Otoritas (Otority) } \\
\text { (Z1.3) }\end{array}$ & $\begin{array}{l}\text { - } \quad \text { Bertanggungjawab terhadap tugas. } \\
\text { - } \quad \text { Kemauan bekerja keras. } \\
\text { - } \quad \text { Menguasai tugas. } \\
\text { - } \quad \text { Mendahulukan kepentingan tugas. } \\
\text { - } \quad \text { Tidak menyalahgunakan wewenang. }\end{array}$ & Ordinal \\
\hline & $\begin{array}{l}\text { Disiplin (Dicipline) } \\
\text { (Z1.4) }\end{array}$ & $\begin{array}{l}\text { - } \quad \text { Taat mematuhi aturan. } \\
\text { - Ketepatan waktu. } \\
\text { - } \text { Menerima resiko. } \\
\text { - Sangsi disesuaikan dengan kesalahan. } \\
\text { - } \quad \text { Bertindak tegas dalam bekerja. }\end{array}$ & Ordinal \\
\hline & $\begin{array}{l}\text { Inisiatif (Inisiative) } \\
\text { (Z1.5) }\end{array}$ & $\begin{array}{l}\text { - } \quad \text { Pertimbangan dan penerimaan usul. } \\
\text { - } \quad \text { Pencari tata kerja baru. } \\
\text { - } \quad \text { Pemberian saran yang baik. } \\
\text { - } \quad \text { Selesaikan masalah tugas. } \\
\text { - Inisiatif meningkatkan kemampuan. }\end{array}$ & Ordinal \\
\hline
\end{tabular}

Sampel yang menjadi sasaran penelitian adalah unsur-unsur yang berada dalam populasi. Penentuan jumlah sampel dari suatu populasi tertentu yang dikembangkan oleh Issac dan Michael untuk tingkat kesalahan $1 \%, 5 \%$, dan $10 \%$ dapat dihitung dengan menggunakan rumus sebagai berikut:

$$
\begin{aligned}
n & =\frac{x^{2} \times N \times P \times Q}{d^{2}(N-1)+x^{2} \times P \times Q} \\
& =\frac{2,706 \times 5.982 \times 0,5 \times 0,5}{(0,05)^{2}(5.982-1)+(2,706) \times(0,5) \times(0,5)} \\
& =\frac{4.046,823}{14,9525+0,6765} \\
& =258,93 \text { (dibulatkan menjadi 259) }
\end{aligned}
$$

Jumlah sampel penelitian menurut stratum cluster perusahaan maupun menurut stratum stratified level jabatan masing-masing perusahaan seperti terlihat pada Tabel 8.

Tabel 8. Jumlah Sampel Karyawan Perusahaan BUMN Industri Pertahanan di Jawa Barat Periode Agustus 2012

\begin{tabular}{lrrrrr}
\hline \multirow{2}{*}{$\begin{array}{c}\text { Perusahaan } \\
\text { BUMNIP }\end{array}$} & \multicolumn{5}{c}{ Populasi/Sampel (Orang) } \\
\cline { 2 - 6 } & Level 1 & Level 2 & Level 3 & Level 4 & \multicolumn{1}{c}{ Total } \\
\hline PT Pindad & $17 / 1$ & $83 / 4$ & $300 / 13$ & $1.205 / 52$ & $1.605 / 70$ \\
PT Dahana & $11 / 1$ & $43 / 2$ & $128 / 5$ & $337 / 14$ & $519 / 22$ \\
PT DI & $26 / 1$ & $93 / 4$ & $441 / 19$ & $2.175 / 94$ & $2.735 / 118$ \\
PT LEN & $14 / 1$ & $37 / 2$ & $240 / 10$ & $154 / 7$ & $445 / 20$ \\
PT Inti & $34 / 1$ & $51 / 2$ & $213 / 9$ & $380 / 17$ & $678 / 29$ \\
Jumlah & $102 / 5$ & $307 / 14$ & $1.322 / 56$ & $4.251 / 184$ & $5.982 / 259$ \\
\hline
\end{tabular}

Sumber: Laporan Perusahaan BUMNIP 2012, diolah oleh peneliti. 


\section{Pengujian Data (Uji Validitas, Uji Realibilitas, dan Uji Normalitas)}

Uji validitas dilakukan untuk melihat apakah instrumen yang digunakan mengukur apa yang seharusnya diukur. Untuk pengujian validitas dalam penelitian ini akan digunakan rumus Korelasi Product Moment yang dikemukakan oleh Pearson sebagai berikut:

$$
r=\frac{\sum X_{i} Y_{i}-1 / n\left(\sum X_{i}\right)\left(\sum Y_{i}\right)}{\sqrt{\left(\sum X_{i}^{2}-1 / n\left(\sum X_{i}\right)^{2}\left[\sum Y_{i}^{2}-1 / n\left(\sum Y_{i}\right)^{2}\right]\right.}}
$$

Keterangan:

$r=$ Koefisien korelasi

$\sum X_{\mathrm{i}}=$ Jumlah skor item

$\sum Y_{\mathrm{i}}=$ Jumlah skor total/seluruh item

$n=$ Jumlah responden

Bila $r_{\text {hitung }} \geq r_{\text {tabel }}$ pada $\alpha=0.05$ berarti data tersebut valid dan layak digunakan dalam pengujian hipotesis penelitian.

Realibitas mengandung pengertian bahwa suatu instrument dapat dipercaya untuk digunakan sebagai alat pengumpul data karena instrumen tersebut sudah baik. Dalam penelitian ini digunakan uji Composite Reliability dan Variance Extracted.

Composite reliability adalah ukuran mengenai konsistensi internal dari indikator-indikator konstruk yang menunjukkan derajat sampai dimana masingmasing indikator itu mengindikasikan sebuah konstruk yang umum. Nilai reliabilitas minimum yang dapat diterima adalah sebesar 0,70 . Untuk mendapatkan nilai tingkat reliabilitas dimensi pembentuk variabel laten (composite reliability) digunakan rumus:

Composite Reliability $=$

$$
\frac{\left(\sum \text { Standard Loading }\right)^{2}}{\left(\sum \text { Standard Loading }\right)^{2}+\sum \varepsilon j}
$$

Pengukuran variance extracted menunjukkan jumlah varians dari indikator yang diekstraksi oleh konstruk/variabel laten yang dikembangkan. Nilai variance extracted yang dapat diterima adalah minimum 0,50 . Persamaan untuk mendapatkan nilai variance extracted adalah:

Variance Extracted =

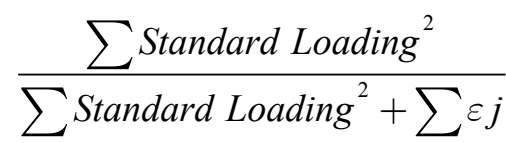

Pengujiannormalitas digunakanuntukmengetahui sebaran data apakah data berdistribusi normal atau tidak. Asumsi normalitas data diuji dengan melihat nilai skewness dan kurtosis dari data yang digunakan. Apabila nilai CR (Critical Ratio) pada skewness maupun kurtosis data berada pada rentang antara \pm 2.58, maka data masih dapat dinyatakan berdistribusi normal (Ferdinand, 2006).

\section{Konversi Data}

Metode yang digunakan untuk menganalisis data penelitian adalah analisis Structural Equation Modelling (SEM). Analisis SEM mensyaratkan data yang digunakan untuk penghitungan harus memiliki skala interval. Sehubungan dengan tingkat pengukuran variabel-variabel penelitian menggunakan skala ordinal, maka data yang berskala ordinal harus dikonversikan menjadi data interval dengan menggunakan metode interval berurutan, Methods of Successive Interval (MSI).

\section{Analisis Deskriptif}

Rumusan masalah yang bersifat deskriptif, dianalisis dengan menggunakan statistik deskriptif. Teknik statistik deskriptif yaitu menghitung rata-rata (mean) dan standar deviasi (standard deviation).

Tabel 9. Klasifikasi Distribusi Frekuensi

\begin{tabular}{clc}
\hline No & \multicolumn{1}{c}{ Kategori } & Interval \\
\hline 1 & Sangat Tidak Baik (STB) & $1,00-1,80$ \\
2 & Tidak Baik (TB) & $1,81-2,60$ \\
3 & Cukup Baik (CB) & $2,61-3,40$ \\
4 & Baik (B) & $3,41-4,20$ \\
5 & Sangat Baik (SB) & $4,21-5,00$ \\
\hline
\end{tabular}

\section{Analisis Verivikatif}

Metode analisis verifikatif untuk menguji hipotesis digunakan metode statistik dengan menggunakan model Structural Equation Modelling (SEM). SEM merupakan suatu teknik statistik yang menganalisis variabel indikator, variabel laten, dan kekeliruan pengukuran. Metode stasitika dengan SEM digunakan untuk mengukur pola hubungan besarnya pengaruh beberapa variabel penyebab (eksogen) terhadap variabel akibat (endogen). 


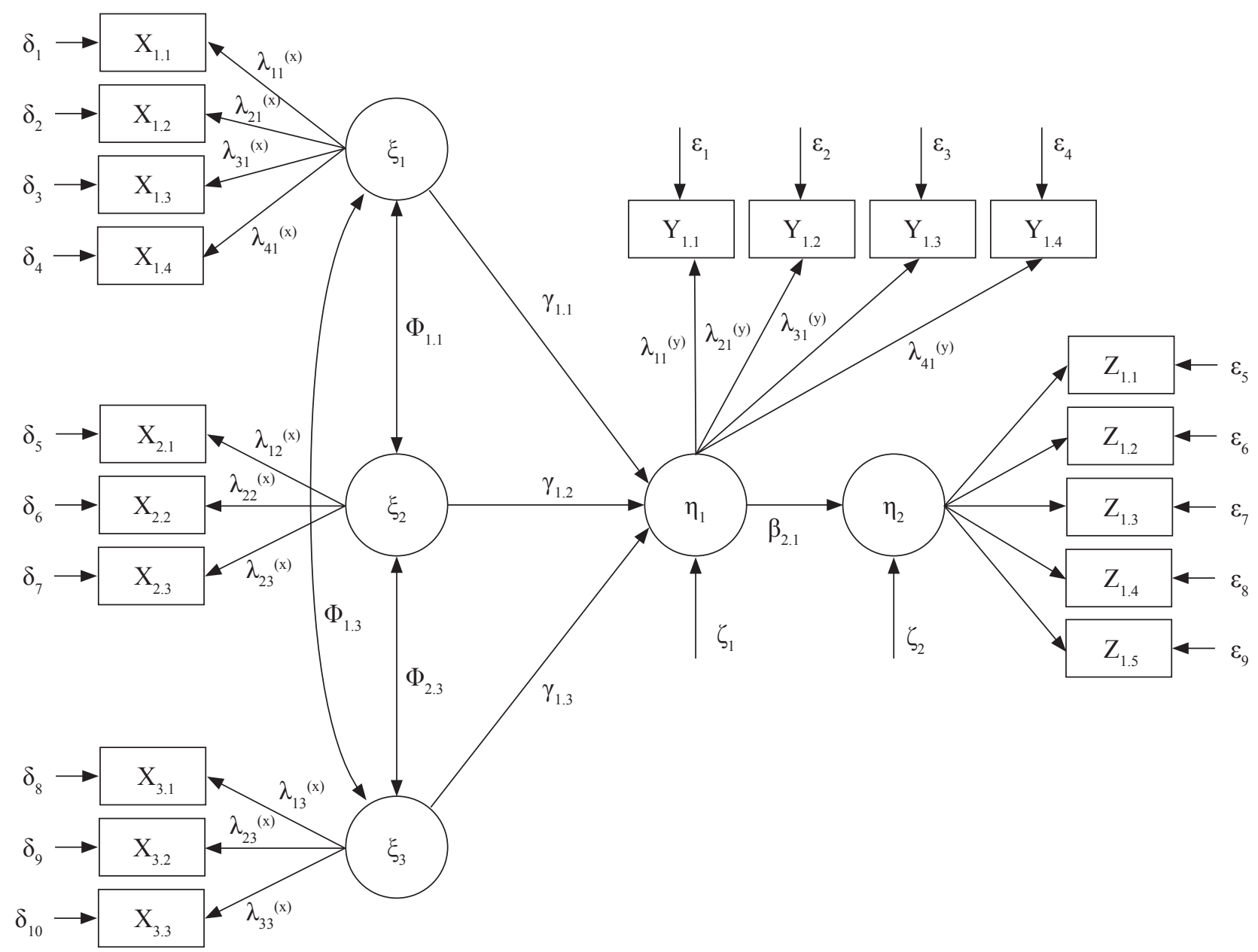

Gambar 2. Struktur Analisis Variabel Penelitian Secara Keseluruhan(SEM)

Selanjutnya kesesuaian model dievaluasi/diuji menggunakan indeks kesesuaian model (Goodness of fit index). Indeks kesesuaian yang digunakan dalam menguji sebuah model dapat diterima atau ditolak, dengan ketentuan seperti terlihat pada Tabel 10.

Tabel 10. Goodness of Fit Index Statistics

\begin{tabular}{clc}
\hline No & Statistics & Kriteria Fit \\
\hline 1 & RMSEA & $\leq 0,08$ \\
2 & GFI & $\geq 0,90$ \\
3 & AGFI & $\geq 0,90$ \\
4 & TLI & $\geq 0,95$ \\
5 & CFI & $\geq 0,95$ \\
6 & CMIN/DF & $\leq 0,20$ \\
\hline
\end{tabular}

Sumber: Hair et.al., 1998.

\section{Uji Hipotesis Simultan}

Hipotesis 1: Kepemimpinan transformasional, komitmen karyawan dan motivasi berpengaruh secara simultan terhadap kepuasan kerja karyawan perusahaan BUMN Industri Pertahanan di Jawa Barat.

Adapun persamaan model struktural sebagai berikut:

$\eta 1=\gamma 1.1 \xi 1+\gamma 1.2 \xi 2+\zeta 1.3 \xi 3+\zeta 1$

Hipotesis statistik sebagai berikut:

$\mathrm{H} 0: \quad \gamma 1.1 \quad \gamma 1.2 \quad \gamma 1.3=0, \quad$ Kepemimpinan Transformasional, Komitmen Karyawan dan Motivasi secara simultan tidak berpengaruh terhadap Kepuasan Kerja.

$\mathrm{H}_{1}: \gamma 1.1 \gamma 1.2 \gamma 1.3 \neq 0$, Kepemimpinan Transformasional, Komitmen Karyawan dan Motivasi secara simultan berpengaruh terhadap Kepuasan Kerja. 
Statistik uji yang digunakan adalah
$F=\frac{(n-p-1) R^{2} \eta}{p\left(1-R^{2} \eta\right)}$

Tolak H0, jika Fhit $>$ Ftabel, pada taraf signifikan, dimana Ftabel $=F[\alpha ;(p, n-p-1)]$

\section{Uji Hipotesis Parsial}

Hipotesis 2: Kepemimpinan Transformasional berpengaruh terhadap Kepuasan Kerja karyawan perusahaan BUMN Industri Pertahanan di Jawa Barat.

Adapun persamaan model struktural sebagai berikut: $\eta 1=\gamma 11 \xi 1+\zeta 1$

Hipotesis statistik sebagai berikut:

H0: $\gamma 1.1=0$, Kepemimpinan Transformasional tidak berpengaruh terhadap Kepuasan Kerja

$\mathrm{H}_{1}: \gamma 1.1 \neq 0$, Kepemimpinan Transformasional berpengaruh terhadap Kepuasan Kerja

Tolak H0, jika $\mathrm{t}$ hitung $>\mathrm{t}$ tabel, pada taraf signifikan, di mana t tabel $=\mathrm{t}(\alpha / 2 ; \mathrm{n}-2)$

Hipotesis 3: Komitmen Karyawan berpengaruh terhadap Kepuasan Kerja karyawan perusahaan BUMN Industri Pertahanan di Jawa Barat.

Adapun persamaan model struktural sebagai berikut: $\eta 1=\gamma 1.2 \xi 2+\zeta 1$

Hipotesis statistik sebagai berikut:

H0: $\gamma 1.2=0$, Komitmen Karyawan tidak berpengaruh terhadap Kepuasan Kerja

$\mathrm{H}_{1}: \gamma 1.2 \neq 0$, Komitmen Karyawan berpengaruh terhadap Kepuasan Kerja

Tolak H0, jika $\mathrm{t}$ hitung $>\mathrm{t}$ tabel, pada taraf signifikan, di mana t tabel $=\mathrm{t}(\alpha / 2 ; \mathrm{n}-2)$

Hipotesis 4: Motivasi Berpengaruh terhadap Kepuasan Kerja karyawan perusahaan BUMN Industri Pertahanan di Jawa Barat.

Adapun persamaan model struktural sebagai berikut: $\eta 1=\gamma 1.3 \xi 3+\zeta 1$

Hipotesis statistik sebagai berikut:

H0: $\gamma 1.3=0$, Motivasi tidak berpengaruh terhadap Kepuasan Kerja

$\mathrm{H}_{1}: \gamma 1.3 \neq 0$, Motivasi berpengaruh terhadap Kepuasan Kerja

Tolak H0, jika $\mathrm{t}$ hitung $>\mathrm{t}$ tabel, pada taraf signifikan, dimana t tabel $=\mathrm{t}(\alpha / 2 ; \mathrm{n}-2)$
Model struktural yang akan diuji adalah sebagai berikut:

Hipotesis 5: Kepuasan Kerja berpengaruh terhadap Kinerja Karyawan perusahaan BUMN Industri Pertahanan di Jawa Barat.

Adapun persamaan model struktural sebagai berikut: $\eta 2=\beta 2.1 \zeta 1+\zeta 2$

Hipotesis statistik sebagai berikut:

H0: $\beta 2.1=0$, Kepuasan Kerja tidak berpengaruh terhadap Kinerja Karyawan.

H1: $\beta 2.1 \neq 0$, Kepuasan Kerja berpengaruh terhadap Kinerja Karyawan.

Tolak H0, jika $\mathrm{t}$ hitung $>\mathrm{t}$ tabel, pada taraf signifikan, dimana $\mathrm{t}$ tabel $=\mathrm{t}(\alpha / 2 ; \mathrm{n}-2)$

\section{Uji Kelayakan Model}

Menurut Wirasasmita (2008) bahwa proses dalam uji kelayakan model penelitian adalah sebagai berikut: 1) Kesesuaian dengan teori (theoritical plausability), hipotesis atau model pasca-estimasi sesuai dengan ekspektasi hipotesis atau model praestimasi; 2) Akurasi estimasi parameter (accuracy of the estimates of the parameters), hipotesis atau model pasca-estimasi menunjukkan akurasi yang tinggi dan tidak bias, yaitu ditunjukkan dengan p-value $<(\alpha=0,05)$ untuk setiap parameter dalam hipotesis atau model; 3) Kemampuan menjelaskan (eksplanatory ability), hipotesis atau model pascaestimasi mempunyai kemampuan menjelaskan yang tinggi, sebagaimana ditunjukkan oleh SE yang rendah, yaitu $<1 / 2$ kali nilai mutlak koefisien regresinya (SE $<1 / 2 \gamma_{\mathrm{ij}}$ ); 4) Kemampuan memprediksi (forecasting ability), model penelitian ini memiliki kemampuan prediksi yang tinggi atas perilaku variabel dependen sebagaimana ditunjukan oleh tingginya koefisien determinasi model yang mendekati atau melebihi $50 \%$.

\section{HASIL}

\section{Profil Perusahaan BUMN Industri Pertahanan di Jawa Barat}

Profil perusahaan BUMNIP di Jawa Barat yang diperlihatkan oleh Visi Misi masing-masing BUMNIP dan bidang usahanya dapat dilihat pada Tabel 11 . 
Tabel 11. Profil Perusahan BUMNIP di Jawa Barat

\begin{tabular}{cl}
\hline No. & \multicolumn{1}{c}{ Visi dan Misi } \\
\hline 1 & Visi PT Pindad (Persero) yaitu menjadi produsen peralatan \\
& hankam terkemuka di Asia pada tahun 2023 melalui \\
& upaya inovasi produk dan kemitraan strategik. \\
& Misi PT Pindad (Persero) adalah melaksanakan usaha \\
& terpadu di bidang peralatan hankam dan peralatan \\
& industrial untuk mendukung pembangunan nasional \\
& dan secara khusus untuk mendukung pertahanan dan \\
& keamanan negara.
\end{tabular}

2 Visi PT Dirgantara Indonesia (PT DI) (Persero) adalah menjadi industri dirgantara kelas dunia yang berbasis pada penguasaan teknologi tinggi dengan mengandalkan keunggulan biaya yang mampu bersaing dalam pasar global.

Misi PT DI adalah menjalankan usaha yang berorientasi pada aspek bisnis dan komersil serta menghasilkan produk dan jasa yang memiliki keunggulan biaya; sebagai pusat keunggulan di bidang industri dirgantara untuk kepentingan komersial dan militer serta melakukan aliansi strategis dengan industri dirgantara kelas dunia lainnya.

3 Visi PT Dahana (Persero) adalah menjadi industri nasional yang terunggul dalam bidang bahan berenergi tinggi dengan menghasilkan barang dan jasa yang berdaya saing tinggi dan ramah lingkungan.

Misinya adalah menyediakan jasa peledakan komersial terpadu, jasa peledakan untuk bidang pertahanan dan jasa pendukung lainnya, mendorong kemampuan penguasaan teknologi dan kemandirian melalui pengembangan kualitas SDM.

4 Visi PT LEN Industri adalah menjadi perusahaan elektronika kelas dunia.

Misi yang diembannya yaitu meningkatkan kesejahteraan stakeholder melalui inovasi produk elektronika industri dan prasarana.

5 Visi Perusahaan PT INTI (Persero) bertujuan menjadi pilihan pertama bagi para pelanggan untuk mentrasformasikan "MIMPI" menjadi "REALITA".

Misi Perusahaan adalah fokus tertuju sepenuhnya pada kegiatan jasa engineering yang sesuai dengan spesifikasi dan permintaan konsumen; dalam menjalankan bisnis PT INTI (Persero) akan berusaha semaksimal mungkin untuk kepentingan pemangku kepentingan (stakeholders).

\section{Bidang Usaha Profil}

PT. Pindad (Persero) dalam melaksanakan kegiatan usahanya, mencakup beberapa bidang yaitu:

1. Manufaktur: Produk senjata dan munisi; Produk kendaraan khusus; Produk piroteknik, bahan pendorong dan bahan peledak; Produk konversi energi; Produk komponen, sarpras bidang transportasi; Produk mesin industri dan peralatan industrial; Produk mekanikal, elektrikal, optikal dan opto elektronik;

2. Jasa: Perekayasaan sistem industrial; Pemeliharaan produk/ peralatan industri; Pengujian mutu dan kalibrasi; Konstruksi; Pemesinan; Heat dan Surface Treatment; Peledakan.

PT. Dirgantara Indonesia (Persero) dalam melaksanakan kegiatan usahanya, mencakup bidang produk manufaktur dan jasa, yaitu:

1. Produk manufaktur, berupa: Aircraft Full Development; Aircraft Joint Development and Production; Aircraft Under License Production; Helicopter Under License Production; Weapon System.

2. Produk Jasa, berupa: Engineering work packages; Manufacturing subcontracts; Aircraft Maintenance Repair and Overhaul (MRO); Engine Maintenance Repair and Overhaul (MRO); Aircraft Industrial Tooling and Equipment Manufacturing.

PT Dahana dalam melaksanakan kegiatan usahanya, terdiri dari beberapa bidang yaitu: Bahan peledak dan Pengembangan industri.

PT LEN Industri (Persero) dalam melaksanakan kegiatan usahanya, mencakup bidang produk elektronika yaitu: System Signaling; Produk Elektronika Daya; Produk Energi Terbarukan; Produk System Control; Produk Elektronika Pertahanan dan Produk Informasi dan Teknologi.

PT INTI (Persero) dalam melaksanakan kegiatan usahanya, mencakup bidang produk telekomunikasi yaitu: Jaringan Telekomunikasi Tetap (JTT); Jaringan Telekomunikasi Selular (JTS); Jasa Integrasi Teknologi (JTT); Jaringan Telekomunikasi Privat (JTP); Outside Plant (OSP) dan Indonesia Surveillance Radar (ISRA) untuk Pertahanan. 


\section{Profil Responden}

Sebagai gambaran umum profil responden terdiri dari responden laki-laki sebesar $73 \%$ sedangkan responden perempuan sebesar $27 \%$. Profil responden berdasarkan usia, tingkat pendidikan, dan masa kerja para karyawan seperti yang terlihat pada Tabel 12., Tabel 13., dan Tabel 14.

Tabel 12. Profil Responden Berdasarkan Usia

\begin{tabular}{cc}
\hline Kelompok Usia & Prosentase Responden (\%) \\
\hline $17-23$ & 10 \\
$24-30$ & 27 \\
$31-37$ & 7 \\
$38-44$ & 9 \\
$45-51$ & 25 \\
$>51$ & 23 \\
\hline
\end{tabular}

Tabel 13. Profil Responden Berdasarkan Tingkat Pendidikan

\begin{tabular}{lc}
\hline \multicolumn{1}{c}{ Tingkat Pendidikan } & Prosentase Responden (\%) \\
\hline SLTA & 38 \\
Diploma & 19 \\
Sarjana & 40 \\
Pascasarjana & 3 \\
\hline
\end{tabular}

Tabel 14. Profil Responden Berdasarkan Tingkat Pendidikan

\begin{tabular}{lc}
\hline \multicolumn{1}{c}{ Masa Kerja } & Prosentase Responden (\%) \\
\hline$\leq 3$ tahun & 19 \\
3 - 6 tahun & 19 \\
6 - 9 tahun & 4 \\
$9-12$ tahun & 1 \\
$12-15$ tahun & 3 \\
$15-18$ tahun & 9 \\
$18-21$ tahun & 7 \\
$>21$ tahun & 38 \\
\hline
\end{tabular}

\section{Hasil Pengujian Validitas Instrumen Variabel- Variabel Penelitian}

Hasil pengujian validitas instrumen variabelvariabel penelitian yang terdiri dari variabel kepemimpinan transformasional, komitmen karyawan, motivasi karyawan, kepuasan kerja, dan kinerja karyawan menunjukkan hasil yang valid, karena semua item pertanyaan untuk semua variabel menunjukkan hasil dimana r-hitung lebih besar dari r-kritis.

\section{Analisis Reliabilitas}

Hasil pengolahan data dari rumus persamaan construct reliability dan variance extracted untuk variabel kepemimpinan transformasional, komitmen karyawan, motivasi, kepuasan kerja dan kinerja karyawan dapat dilihat pada Tabel 15.

Tabel 15. Nilai Construct Reliability dan Variance Extracted Variabel Konstruk (Laten)

\begin{tabular}{lccccc}
\hline \multicolumn{1}{c}{$\begin{array}{c}\text { Variabel } \\
\text { Konstruk }\end{array}$} & $\begin{array}{c}\text { Construct } \\
\text { reliability }\end{array}$ & $\begin{array}{c}\text { Kritisi } \\
\text { Kritiance }\end{array}$ & $\begin{array}{c}\text { Varianted } \\
\text { Extracted }\end{array}$ & Keterangan \\
\hline $\begin{array}{l}\text { Kepemimpinan } \\
\text { Transformasional }\end{array}$ & 0,851 & 0,70 & 0,773 & 0,50 & Reliabel \\
$\begin{array}{l}\text { Komitmen } \\
\text { Karyawan }\end{array}$ & 0,777 & 0,70 & 0,657 & 0,50 & Reliabel \\
Motivasi & 0,703 & 0,70 & 0,515 & 0,50 & Reliabel \\
Kepuasan Kerja & 0,800 & 0,70 & 0,671 & 0,50 & Reliabel \\
Kinerja Karyawan & 0,811 & 0,70 & 0,679 & 0,50 & Reliabel \\
\hline
\end{tabular}

Sumber: Data primer, diolah, 2013

\section{Analisis Normalitas Data}

Berdasarkan hasil pengolahan data penelitian menunjukkan bahwa semua nilai CR untuk skewness (univariate) berada pada rentang $\pm 2,58$, sedangkan untuk uji normalitas multivariate memberikan nilai CR kurtosis 1,817 yang berada pada rentang \pm 2,58. Jadi uji normalitas secara univariate maupun multivariate menunjukkan bahwa data berdistribusi normal (lihat Tabel 16.).

\section{Analisis Deskripsi Variabel-Variabel Penelitian}

Analisis deskripsi variabel-variabel penelitian dapat dilihat pada Tabel 17. sampai dengan Tabel 21. 
Tabel 16. Assessment of Normality

\begin{tabular}{|c|c|c|c|c|c|c|c|}
\hline Variabel & Dimensi & Min & Max & Skew & C.R. & Kurtosis & C.R. \\
\hline \multirow[t]{5}{*}{ Kinerja Karyawan } & $\mathrm{Z} 5$ & 6,000 & 26,886 & $-0,298$ & $-1,961$ & 0,757 & 2,486 \\
\hline & Z4 & 19,287 & 46,486 & 0,174 & 1,141 & $-0,038$ & $-0,125$ \\
\hline & Z3 & 13,961 & 41,808 & $-0,295$ & $-1,941$ & 0,310 & 1,018 \\
\hline & $\mathrm{Z} 2$ & 10,718 & 34,429 & $-0,184$ & $-1,209$ & $-0,137$ & $-0,451$ \\
\hline & Z1 & 8,940 & 28,662 & $-0,390$ & $-2,563$ & 0,464 & 1,524 \\
\hline \multirow[t]{4}{*}{ Kepuasan Kerja } & Y4 & 16,615 & 46,486 & $-0,279$ & $-1,831$ & 0,136 & 0,446 \\
\hline & Y3 & 10,539 & 41,389 & $-0,257$ & $-1,690$ & $-0,248$ & $-0,816$ \\
\hline & Y2 & 7,000 & 34,429 & $-0,268$ & $-1,762$ & $-0,245$ & $-0,806$ \\
\hline & Y1 & 8,599 & 29,872 & $-0,336$ & $-2,210$ & 0,326 & 1,073 \\
\hline \multirow[t]{3}{*}{ Motivasi } & X31 & 13,449 & 33,420 & $-0,037$ & $-0,245$ & $-0,384$ & $-1,260$ \\
\hline & X32 & 19,438 & 41,888 & $-0,035$ & $-0,228$ & 0,665 & 2,186 \\
\hline & X33 & 10,304 & 30,788 & $-0,036$ & $-0,236$ & $-0,751$ & $-2,468$ \\
\hline \multirow[t]{3}{*}{ Komitmen Karyawan } & $X 21$ & 13,331 & 40,141 & $-0,362$ & $-2,380$ & 0,049 & 0,162 \\
\hline & $x 22$ & 7,659 & 25,081 & $-0,392$ & $-2,577$ & 0,020 & 0,065 \\
\hline & $\mathrm{X} 23$ & 6,037 & 23,288 & $-0,168$ & $-1,106$ & 0,218 & 0,716 \\
\hline \multirow[t]{5}{*}{ Kepemimpinan Transformasional } & $\mathrm{X} 11$ & 7,710 & 29,010 & $-0,418$ & $-2,544$ & 0,143 & 0,470 \\
\hline & $\mathrm{X} 12$ & 7,704 & 29,462 & $-0,319$ & $-2,097$ & $-0,200$ & $-0,657$ \\
\hline & $\mathrm{X} 13$ & 8,998 & 30,087 & $-0,453$ & $-2,574$ & $-0,045$ & $-0,147$ \\
\hline & $\mathrm{X} 14$ & 6,842 & 28,487 & $-0,569$ & $-2,540$ & $-0,144$ & $-0,474$ \\
\hline & Multivarate & & & & & 6,568 & 1,817 \\
\hline
\end{tabular}

Tabel 17. Rekapitulasi Variabel Kepemimpinan Transformasional

\begin{tabular}{lccccc}
\hline \multicolumn{1}{c}{ Dimensi } & Nilai Rata-rata & Std. Deviasi & Rentang Nilai & Kategori & Temuan Penelitian \\
\hline Pengaruh Ideal & 3,877 & 0,813 & 3.064 s.d 4,690 & Cukup kuat -sangat kuat & Tertinggi \\
Motivasi Inspirasional & 3,726 & 0,849 & 2,877 s.d 4,575 & Cukup kuat - sangat kuat & Moderate \\
Stimulasi Intelektual & 3,830 & 0,827 & 3,003 s.d 4,657 & Cukup kuat - sangat kuat & Moderate \\
Perhatian Individu & 3,686 & 0,866 & 2,820 s.d 4,552 & Cukup kuat - sangat kuat & Terendah \\
Kepemimpinan & 3,780 & 0,839 & 2,941 s.d 4,619 & Cukup kuat- sangat kuat & Cukup kuat- sangat kuat \\
Transformasional & & & &
\end{tabular}

Tabel 18. Rekapitulasi Variabel Komitmen Karyawan

\begin{tabular}{lccccc}
\hline \multicolumn{1}{c}{ Dimensi } & Nilai Rata-rata & Std. Deviasi & Rentang Nilai & Kategori & Temuan Penelitian \\
\hline $\begin{array}{l}\text { Komitmen Afektif } \\
\text { Komitmen }\end{array}$ & 3,868 & 0,789 & 3,079 s.d 4,657 & Cukup tinggi - sangat tinggi & Moderate \\
Berkelanjutan & 3,761 & 0,884 & 2,877 s.d 4,645 & Cukup tinggi - sangat tinggi & Terendah \\
Komitmen Normatif & 3,941 & 0,724 & 3,217 s.d 4,665 & Cukup tinggi - sangat tinggi & Tertinggi \\
Komitmen Karyawan & 3,857 & 0,799 & 3,058 s.d 4,656 & Cukup tinggi- sangat tinggi & Cukup tinggi - sangat tinggi \\
\hline
\end{tabular}


Tabel 19. Rekapitulasi Variabel Motivasi

\begin{tabular}{|c|c|c|c|c|c|}
\hline Dimensi & Nilai Rata-rata & Std. Deviasi & Rentang Nilai & Kategori & Temuan Penelitian \\
\hline Kebutuhan Berprestasi & 4,073 & 0,727 & 3,346 s.d 4,800 & Cukup tinggi - Sangat tinggi & Tertinggi \\
\hline Kebutuhan Berafiliasi & 4,039 & 0,674 & 3,365 s.d 4,713 & Cukup tinggi - Sangat tinggi & Moderat \\
\hline Kebutuhan Berkuasa & 3,509 & 0,910 & 2,599 s.d 4,419 & Cukup tinggi- Sangat tinggi & Terendah \\
\hline Motivasi & 3,874 & 0,770 & 3,104 s.d 4,644 & Cukup tinggi- Sangat tinggi & Cukup tinggi- Sangat tinggi \\
\hline
\end{tabular}

Tabel 20. Rekapitulasi Variabel Kepuasan Kerja

\begin{tabular}{lccccl}
\hline \multicolumn{1}{c}{ Dimensi } & Nilai Rata-rata & Std. Deviasi & Rentang Nilai & Kategori & Temuan Penelitian \\
\hline Faktor Psikologi & 3,858 & 0,752 & 3.106 s.d 4,610 & Cukup puas - Sangat puas & Tertinggi \\
Faktor Finansial & 3,354 & 0,995 & 2,359 s.d 4,349 & Cukup puas - Sangat puas & Terendah \\
Faktor Fisik & 3,621 & 0,901 & 2,720 s.d 4,522 & Cukup puas - Sangat puas & Moderate \\
Faktor Sosial & 3,694 & 0,803 & 2,891 s.d 4,497 & Cukup puas - Sangat puas & Moderate \\
Kepuasan Kerja & 3,632 & 0,863 & 2,769 s.d 4,495 & Cukup puas - Sangat puas & Cukup puas - Sangat puas \\
\hline
\end{tabular}

Tabel 21. Rekapitulasi Variabel Kinerja Karyawan

\begin{tabular}{lccccl}
\hline \multicolumn{1}{c}{ Dimensi } & Nilai Rata-rata & Std. Deviasi & Rentang Nilai & Kategori & Temuan Penelitian \\
\hline $\begin{array}{l}\text { Kemampuan } \\
\text { Efektivitas }\end{array}$ & 4,101 & 0,664 & 3,437 s.d 4,765 & Cukup tinggi - Sangat tinggi & Tertinggi \\
dan Efisiensi & 4,007 & 0,567 & 3,440 s.d 4,574 & Cukup tinggi - Sangat baik & Moderat \\
Otoritas & 4,099 & 0,633 & 3,466 s.d 4,732 & Cukup tinggi - Sangat tinggi & Moderat \\
Disiplin & 3,980 & 0,757 & 3,223 s.d 4,737 & Cukup tinggi- Sangat tinggi & Terendah \\
Inisiatif & 3,993 & 0,676 & 3,317 s.d 4,669 & Cukup tinggi - Sangat tinggi & Moderat \\
Kinerja Karyawan & 4,036 & 0,659 & 3,377 s.d 4,695 & Cukup tinggi - Sangat tinggi & Cukup tinggi - Sangat tinggi \\
\hline
\end{tabular}

Tabel 22. Hasil Pengujian Kelayakan Model Confirmatory Factor Analysis-1

\begin{tabular}{lccc}
\hline \multicolumn{1}{c}{ Goodness of Fit Indeks } & Cut-off Value & Hasil Analisis & Evaluasi Model \\
\hline RMSEA & $\leq 0,08$ & 0,054 & Model fit \\
GFI & $\geq 0,90$ & 0,960 & Model fit \\
AGFI & $\geq 0,90$ & 0,931 & Model fit \\
TLI & $\geq 0,95$ & 0,962 & Model fit \\
CFI & $\geq 0,95$ & 0,973 & Model fit \\
CMIN/DF & $\leq 2,00$ & 1,747 & Model fit \\
\hline
\end{tabular}

Tabel 23. Standarisasi Regression Weights Confirmatory Factor Analysis Konstruk Eksogen

\begin{tabular}{lllccccc}
\hline & & Relationship & Estimate & S.E. & C.R. & P & Std.Est \\
\hline$X_{14} \leftarrow$ & Kepim_Transform-X & 1,000 & 0,089 & 11,244 & $* * *$ & 0,729 \\
$X_{13} \leftarrow$ & Kepim_Transform_X1 & 1,041 & 0,090 & 11,549 & $* * *$ & 0,777 \\
$X_{12} \leftarrow$ & Kepim_Transform_X & 1,173 & 0,095 & 12,322 & $* * *$ & 0,851 \\
$X_{11}$ & $\leftarrow$ & Kepim_Transform_X & 0,934 & 0,088 & 10,605 & $* * *$ & 0,710 \\
$X_{23}$ & $\leftarrow$ & KomitmenKaryawan_X2 & 1,000 & 0,098 & 8,746 & $* * *$ & 0,618 \\
$X_{22}$ & $\leftarrow$ & KomitmenKaryawan_X2 & 1,196 & 0,135 & 8,882 & $* * *$ & 0,741 \\
$X_{21}$ & $\leftarrow$ & KomitmenKaryawan_X2 & 2,099 & 0,229 & 9,160 & $* * *$ & 0,833 \\
$X_{33}$ & $\leftarrow$ & Motivasi_X3 & 1,000 & 0,136 & 7,842 & $* * *$ & 0,616 \\
$X_{32}$ & $\leftarrow$ & Motivasi_X3 & 0,982 & 0,147 & 6,693 & $* * *$ & 0,610 \\
$X_{31}$ & $\leftarrow$ & Motivasi_X3 & 1,086 & 0,157 & 6,922 & $* * *$ & 0,761 \\
\hline
\end{tabular}




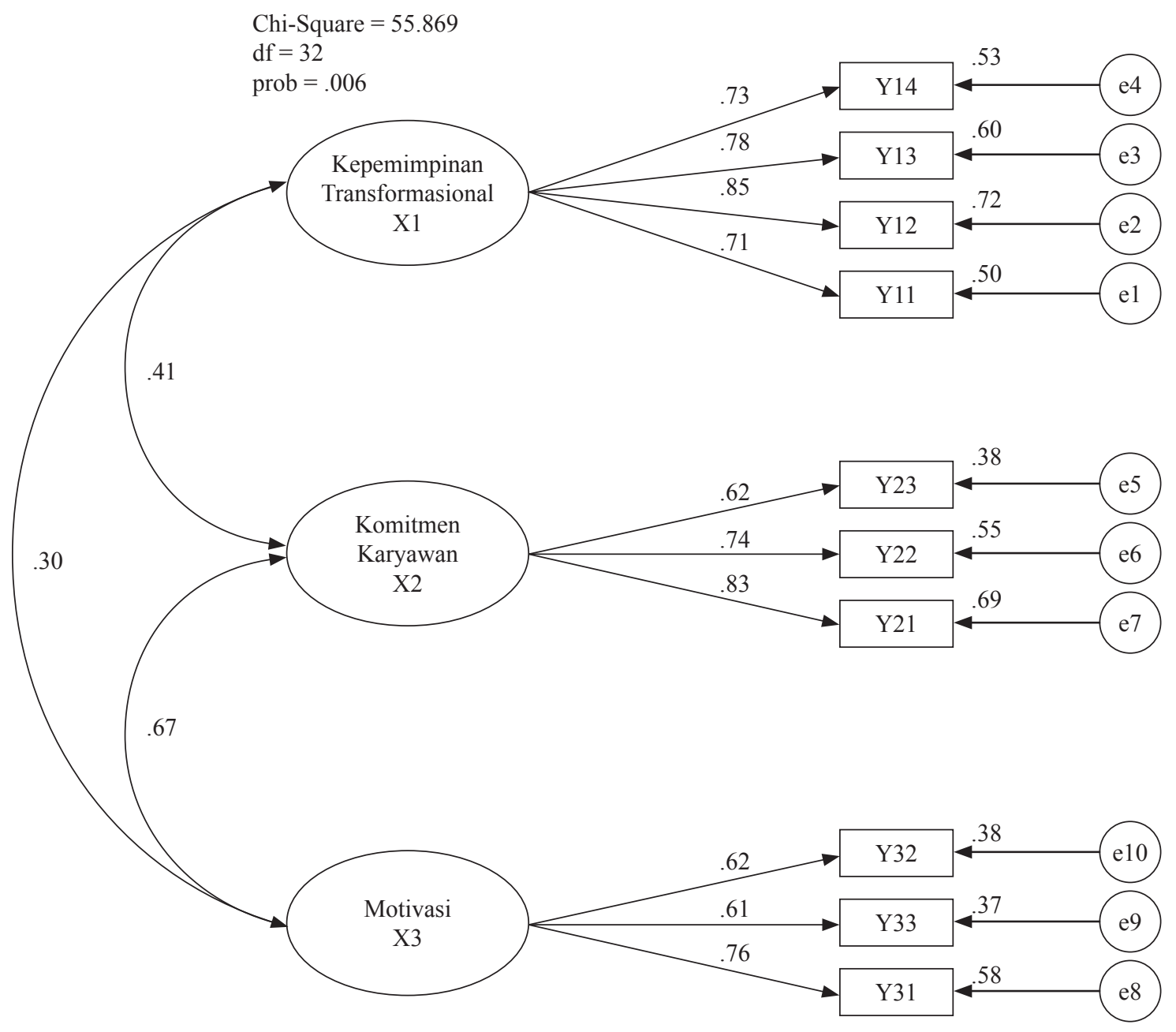

Keterangan Gambar:

Kepemiminan Transformasional $\left(\mathrm{X}_{1}\right)$ :

$\mathrm{X}_{11}$ : Pengaruh Ideal (Idealized Influence)

$\mathrm{X}_{12}$ : Motivasi Inspirasional (Inspirational Motivation)

$\mathrm{X}_{13}$ : Stimulasi Intelektual (Intellectual Stimulation)

$\mathrm{X}_{14}$ : Perhatian Individu (Individual Consideration)

Komitmen Karyawan $\left(\mathrm{X}_{2}\right)$ :

$\mathrm{X}_{21}$ : Komitmen Afektif (Affective Commitment)

$\mathrm{X}_{22}$ : Komitmen Berkelanjutan (Continuance Commitment)

$\mathrm{X}_{23}$ : Komitmen Normatif (Normative Commitment)

$\operatorname{Motivasi}\left(\mathrm{X}_{3}\right)$ :

$\mathrm{X}_{31}$ : Kebutuhan Berprestasi (Need for Achievement)

$\mathrm{X}_{32}$ : Kebutuhan Berafiliasi (Need for Affiliation)

$\mathrm{X}_{33}$ : Kebutuhan Kekuasaan (Need for Power)

Gambar 3. Analisis Faktor Konfirmatori Konstruk Eksogen 


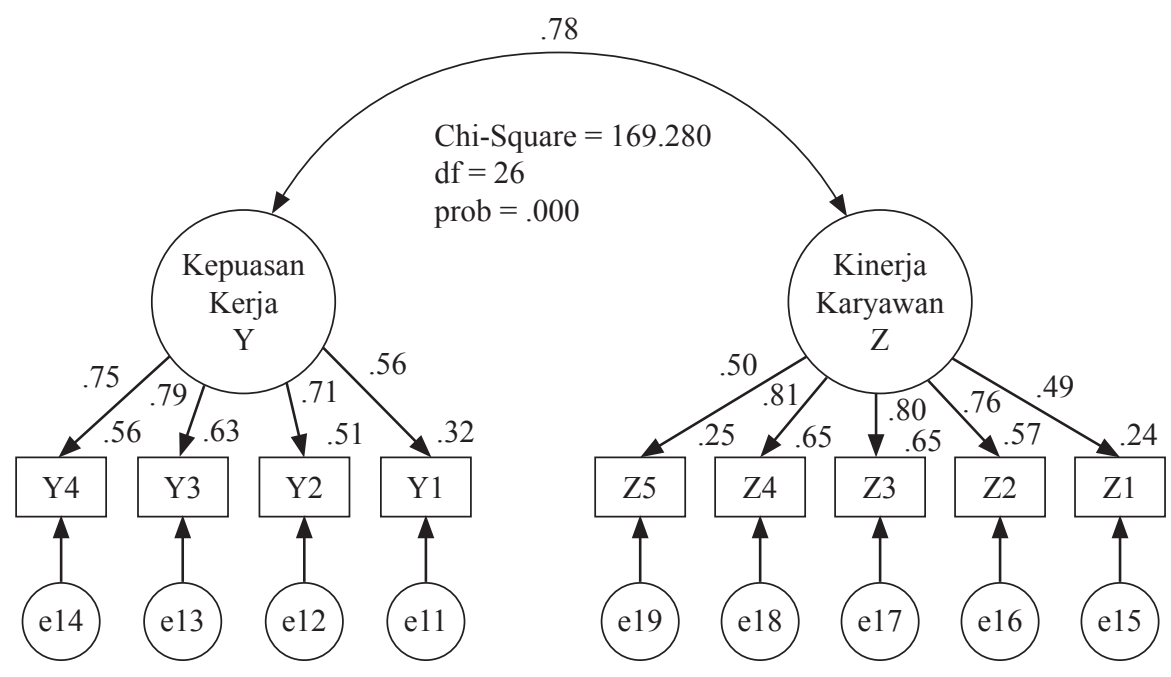

Sumber: data primer, diolah, 2013
Keterangan Gambar:

Kepuasan Kerja (Y)

$\mathrm{Y}_{1}$ : Faktor psikologi

$\mathrm{Y}_{2}$ : Faktor finansial

$\mathrm{Y}_{3}$ : Faktor fisik

$\mathrm{Y}_{4}$ : Faktor sosial

Kinerja Karyawan (Z)

Z1 : Kemampuan (ability)

$\mathrm{Z} 2$ : Efektifitas dan efisiensi (effectivity and efficiency)

Z3 : Otoritas (otority)

Gambar 4. Analisis Faktor

Konfirmatori Konstruk Endogen

\section{Analisis Verifikatif}

Metode analisis verifikatif digunakan metode statistik berupa Structural Equation Modelling (SEM). Pada analisis verivikatif akan dijelaskan mengenai model pengukuran dalam SEM dan model struktural dalam SEM (Gambar 3.).

Ringkasan uji kelayakan model confirmatory factor analysis konstruk eksogen tersebut terlihat pada Tabel 22. dan Tabel 23.

Persamaan model dimensional kepemimpinan transformasional sebagai berikut.

$\mathrm{X}_{11}=0,710 \mathrm{X}_{1}+0,50$

$\mathrm{X}_{12}=0,851 \mathrm{X}_{1}+0,72$

$\mathrm{X}_{13}=0,777 \mathrm{X}_{1}+0,60$

$\mathrm{X}_{14}=0,729 \mathrm{X}_{1}+0,53$

Pada variabel kepemimpinan transformasional $\left(\mathrm{X}_{1}\right)$, dimensi pengaruh ideal (Idealized Influence, $X_{11}$ ) merupakan nilai koefisien jalur terkecil, dapat memprediksi kepemimpinan transformasional sebesar $(0,710)^{2}$ atau sebesar $50,410 \%$. dan dimensi motivasi inspirasional (inspirational motivation, $\mathrm{X}_{12}$ ) merupakan jalur terbesar, dengan nilai koefisien sebesar $(0,851)^{2}$ atau sebesar $72,420 \%$.

Persamaan model dimensional komitmen karyawan sebagai berikut:

$X_{21}=0,833 X_{2}+0,69$

$X_{22}=0,741 X_{2}+0,5$

$X_{23}=0,618 X_{2}+0,38$
Dimensi Komitmen normatif merupakan nilai koefisien jalur terkecil, yang dapat memprediksi komitmen karyawan sebesar $(0,618)^{2}$ atau sebesar $38,192 \%$. Dimensi komitmen afektif merupakan jalur terbesar, dengan nilai koefisien sebesar $(0,833)^{2}$ atau sebesar 69,388\%.

Persamaan model dimensional motivasi $\left(\mathrm{X}_{3}\right)$ sebagai berikut:

$\mathrm{X}_{31}=0,761 \mathrm{X}_{3}+0,44$

$X_{32}=0,610 X_{3}+0,37$

$X_{33}=0,616 X_{3}+0,38$

Dimensi kebutuhan berafiliasi (Need for affiliation) merupakan nilai koefisien jalur terkecil, yang dapat memprediksi motivasi sebesar $(0,610)^{2}$ atau sebesar 37,210\%. Dimensi kebutuhan berprestasi (need for achievement) merupakan jalur terbesar, dengan nilai koefisien sebesar $(0,761)^{2}$ atau sebesar 57,912\%.

Tahap analisis fakor konfirmatori konstruk endogen ini sama dengan tahap analisis faktor konfirmatori konstruk eksogen. Hasil pengolahan data analisis faktor konfirmatori konstruk eksogen terlihat pada Gambar 4.

Hasil analisis pengolahan data terlihat bahwa semua konstruk yang digunakan untuk membentuk sebuah model penelitian, pada proses analisis faktor konfirmatori telah memenuhi kriteria goodness of fit yang telah ditetapkan. 
Tabel 24. Hasil Pengujian Kelayakan Model Confirmatory Factor Analysis-2

\begin{tabular}{lccc}
\hline $\begin{array}{c}\text { Goodness of } \\
\text { Fit Indeks }\end{array}$ & $\begin{array}{c}\text { Cut-off } \\
\text { Value }\end{array}$ & $\begin{array}{c}\text { Hasil } \\
\text { Analisis }\end{array}$ & $\begin{array}{c}\text { Evaluasi } \\
\text { Model }\end{array}$ \\
\hline RMSEA & $\leq 0,08$ & 0,084 & Marginal \\
GFI & $\geq 0,90$ & 0,875 & Marginal \\
AGFI & $\geq 0,90$ & 0,917 & Model fit \\
TLI & $\geq 0,95$ & 0,952 & Model fit \\
CFI & $\geq 0,95$ & 0,957 & Model fit \\
CMIN/DF & $\leq 2,00$ & 2,000 & Model fit \\
\hline
\end{tabular}

Hasil pengujian terhadap nilai-nilai muatan faktor (loading factor) untuk masing-masing indikator dapat dilihat pada Tabel 25.

Berdasarkan analisis tersebut maka model penelitian ini dapat dianalisis lebih lanjut tanpa adanya modifikasi ataupun penyesuaian.

Persamaan model dimensional kepuasan kerja sebagai berikut:

$\mathrm{Y}_{1}=0,562 \mathrm{Y}+0,32$

$\mathrm{Y}_{2}=0,714 \mathrm{Y}+0,51$

$\mathrm{Y}_{3}=0,791 \mathrm{Y}+0,63$

$\mathrm{Y}_{4}=0,749 \mathrm{Y}+0,56$

Pada variabel kepuasan kerja (Y), dimensi faktor psikologi $\left(\mathrm{Y}_{1}\right)$ merupakan nilai koefisien jalur terkecil, dapat memprediksi kepuasan kerja sebesar $(0,562)^{2}$ atau sebesar $31,258 \%$. Dimensi faktor fisik $\left(\mathrm{Y}_{3}\right)$ merupakan jalur terbesar, dengan nilai koefisien sebesar $(0,791)^{2}$ atau sebesar $62,568 \%$.
Persamaan model dimensional kinerja karyawan sebagai berikut:

$Z_{1}=0,593 \mathrm{Z}+0,24$

$Z_{2}=0,756 Z+0,57$

$Z_{3}=0,804 Z+0,65$

$Z_{4}=0,808 \mathrm{Z}+0,65$

$Z_{5}=0,505 \mathrm{Z}+0,25$

Pada variabel kinerja karyawan (Z), dimensi inisiatif (inisiative) merupakan nilai koefisien jalur terkecil, dapat memprediksi kinerja karyawan sebesar $(0,505)^{2}$ atau sebesar $25,503 \%$. Dimensi disiplin (dicipline) merupakan jalur terbesar, dengan nilai koefisien sebesar $(0,808)^{2}$ atau sebesar $65,286 \%$.

\section{Analisis Model Struktural dalam SEM}

Uji kelayakan model keseluruhan dilakukan dengan menggunakan analisis SEM, Dalam penelitian ini terdapat 3 faktor eksogenus yang merupakan latent variable dengan 10 observed variable sebagai dimensi pembentuknya serta 2 faktor endogen yang merupakan latent variable dengan 9 observed variable sebagai dimensi pembentuknya. Tujuan analisis konfirmatori ini untuk menguji unidimensionalitas dari dimensidimensi pembentuk seluruh faktor (latent variablel unobserved variable). Hasil pengujian model melalui SEM adalah seperti yang ditampilkan dalam Gambar 5. Dari Gambar 5. dapat dijelaskan persamaan struktur dalam SEM dan nilai korelasi (r) antar variabel eksogenus, sebagai berikut 1) Kepuasan Kerja $\left.(\mathrm{Y})=0,29 \mathrm{X} 1+0,23 \mathrm{X} 2+0,45 \mathrm{X} 3+0,61 \mathrm{e}_{20} ; 2\right)$ Kinerja Karyawan $\left.(Z)=0,83 \mathrm{Y}+0,68 \mathrm{e}_{21} \cdot 3\right)$ Korelasi antara $\mathrm{X}_{1}$ dengan $X_{2}=0,41$; 4) Korelasi antara $X_{1}$ dengan $X_{3}=$ 0,30 ; dan 5) Korelasi antara $X_{2}$ dengan $X_{3}=0,67$

Tabel 25. Standarisasi Regression Weights Confirmatory Factor Analysis Konstruk Endogen

\begin{tabular}{|c|c|c|c|c|c|c|c|}
\hline & & Relationship & Estimate & SE & CR & $\mathbf{P}$ & Std.Est \\
\hline Z2 & $\leftarrow$ & Kinerja_Karyawan_Z & 1,914 & 0,255 & 7,516 & $* * *$ & 0,756 \\
\hline Z3 & $\leftarrow$ & Kinerja_Karyawan_Z & 2,510 & 0,326 & 7,701 & $* * *$ & 0,804 \\
\hline Z4 & $\leftarrow$ & Kinerja_Karyawan_Z & 2,282 & 0,296 & 7,714 & $* * *$ & 0,808 \\
\hline Z5 & $\leftarrow$ & Kinerja_Karyawan_Z & 1,028 & 0,171 & 6,013 & $* * *$ & 0,505 \\
\hline $\mathrm{Z1}$ & $\leftarrow$ & Kinerja_Karyawan_Z & 1,000 & 0,124 & 6,025 & $* * *$ & 0,593 \\
\hline Y1 & $\leftarrow$ & Kepuasan_Kerja_Y & 1,000 & 0,153 & 8,325 & $* * *$ & 0,562 \\
\hline Y2 & $\leftarrow$ & Kepuasan_Kerja_Y & 1,627 & 0,199 & 8,157 & $* * *$ & 0,714 \\
\hline Y3 & $\leftarrow$ & Kepuasan_Kerja_Y & 1,995 & 0,232 & 8,594 & $* * *$ & 0,791 \\
\hline Y4 & $\leftarrow$ & Kepuasan_Kerja_Y & 1,809 & 0,216 & 8,368 & $* * *$ & 0,749 \\
\hline
\end{tabular}




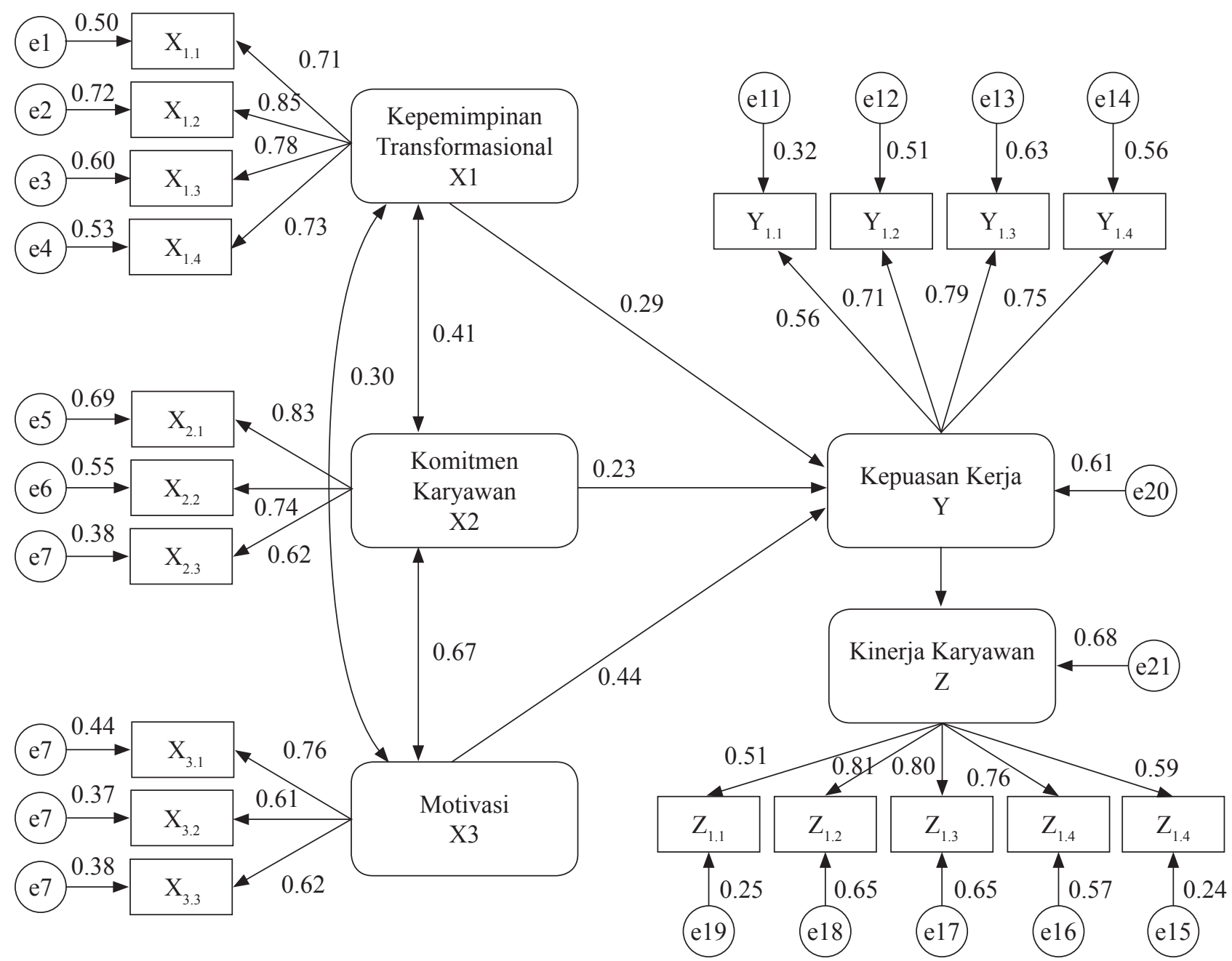

Gambar 5. Hasil Analisis Structural Equation Model (SEM)

Ringkasan uji kelayakan model confirmatory factor analysis tersebut adalah sebagai berikut.

Tabel 26. Hasil Pengujian Kelayakan Full Model SEM

\begin{tabular}{lccc}
\hline $\begin{array}{c}\text { Goodness of } \\
\text { Fit Indeks }\end{array}$ & $\begin{array}{c}\text { Cut-off } \\
\text { Value }\end{array}$ & $\begin{array}{c}\text { Hasil } \\
\text { Analisis }\end{array}$ & $\begin{array}{c}\text { Evaluasi } \\
\text { Model }\end{array}$ \\
\hline RMSEA & $\leq 0,08$ & 0,080 & Model fit \\
GFI & $\geq 0,90$ & 0,857 & Marginal \\
AGFI & $\geq 0,90$ & 0,913 & Model fit \\
TLI & $\geq 0,95$ & 0,954 & Model fit \\
CFI & $\geq 0,95$ & 0,952 & Model fit \\
CMIN/DF & $\leq 2,00$ & 2,030 & Marginal \\
\hline
\end{tabular}

Hasil analisis pengolahan data terlihat bahwa semua konstruk yang digunakan untuk membentuk sebuah model penelitian, pada proses analisis full model SEM memenuhi kriteria goodness of fit yang telah ditetapkan. Sehingga secara keseluruhan berarti model tersebut memiliki kemampuan yang baik dalam pengujian kelayakan model dalam SEM.

Untuk uji statistik terhadap hubungan antar variabel yang nantinya digunakan sebagai dasar untuk menjawab hipotesis penelitian yang telah diajukan. Uji statistik hasil pengolahan dengan SEM dilakukan dengan melihat tingkat signifikansi hubungan antar variabel yang diperlihatkan melalui nilai probabilitas (p) dan critical ratio (CR) masing-masing hubungan antar variabel. 
Tabel 27. Standarisasi Regression Weight

\begin{tabular}{llccccc}
\hline & Relationship & Estimte & Std.Est & SE & CR & P \\
\hline Kepuasan_Kerja_Y & $\leftarrow$ Komitmen_Karyawan_X2 & 0,267 & 0,228 & 0,106 & 2,115 & 0,034 \\
Kepuasan_Kerja_Y & $\leftarrow$ Motivasi_X3 & 0,374 & 0,451 & 0,101 & 3,691 & $* * *$ \\
Kepuasan_Kerja_Y & $\leftarrow$ KepemimpinanTransformasional_X1 & 0,225 & 0,287 & 0,055 & 4,073 & $* * *$ \\
Kinerja_Karyawan_Z & $\leftarrow$ KepuasanKerja_Y & 0,621 & 0,826 & 0,098 & 6,317 & $* * *$ \\
\hline
\end{tabular}

Tabel 28. Pengaruh Langsung dan Tidak Langsung Variabel Kepemimpinan Transformasional, Komitmen Karyawan dan Motivasi terhadap Kepuasan Kerja

\begin{tabular}{|c|c|c|c|c|c|c|}
\hline \multirow[b]{2}{*}{ Variabel } & \multirow{2}{*}{$\begin{array}{l}\text { Pengaruh } \\
\text { Langsung } \\
\quad(1)\end{array}$} & \multicolumn{3}{|c|}{ Pengaruh Tidak Langsung } & \multirow{2}{*}{$\begin{array}{c}\text { Jumlah } \\
\text { Pengaruh Tidak } \\
\text { Langsung (2) }\end{array}$} & \multirow{2}{*}{$\begin{array}{l}\text { Total } \\
(1+2)\end{array}$} \\
\hline & & $\begin{array}{l}\text { Kepemimpinan } \\
\text { Transformasional }\end{array}$ & $\begin{array}{l}\text { Komitmen } \\
\text { Karyawan }\end{array}$ & Motivasi & & \\
\hline Kepemimpinan Transformasional & $8,410 \%$ & & $2,735 \%$ & $3,915 \%$ & $6,650 \%$ & $15,060 \%$ \\
\hline Komitmen Karyawan & $5,290 \%$ & $2,735 \%$ & & $6,935 \%$ & $9,670 \%$ & $14,960 \%$ \\
\hline \multirow[t]{3}{*}{ Motivasi } & $20,340 \%$ & $3,915 \%$ & $6,935 \%$ & & $10,850 \%$ & $31,190 \%$ \\
\hline & & & & & Total & $61,210 \%$ \\
\hline & & & & & Epsilon & $38,790 \%$ \\
\hline
\end{tabular}

Selanjutnya, untuk mengetahui kontribusi pengaruh yang diberikan oleh masing-masing variabel eksogenus baik secara langsung maupun tidak langsung terhadap variabel endogenus dapat diuraikan pada analisis berikut ini.

Kontribusi Pengaruh Kepemimpinan Transformasional, Komitmen Karyawan dan Motivasi terhadap Kepuasan Kerja Karyawan.

Pengaruh secara bersama-sama (simultan) maupun parsial dari kepemimpinan transformasional, komitmen karyawan dan motivasi terhadap kepuasan kerja karyawan yang dinilai dari pengaruh langsung dan pengaruh tidak langsung, dapat diuraikan pada Tabel 28.

Melalui analisis data tersebut dapat diketahui bahwa besarnya total pengaruh secara simultan dari variabel kepemimpinan transformasional, komitmen karyawan dan motivasi sebesar 61,210\%. Hal ini menunjukkan bahwa kepemimpinan transformasional, komitmen karyawan dan motivasi cukup tinggi dalam mempengaruhi kepuasan kerja, sementara sisanya $38,790 \%$ dijelaskan oleh faktor lain di luar model yang diteliti.

\section{Kontribusi Pengaruh Kepuasan Kerja terhadap Kinerja Karyawan}

Berdasarkan Gambar Hasil Analisis SEM diperoleh nilai koefisien jalur untuk kepuasan kerja terhadap kinerja karyawan sebesar 0,83, sehingga kontribusi pengaruh dari kepuasan kerja terhadap kinerja karyawan sebesar $(0,83)^{2}$ atau sebesar $68,890 \%$ dan nilai epsilon model pengaruh kepuasan kerja terhadap kinerja karyawan sebesar 31,110\%. Nilai epsilon dipengaruhi oleh faktor lain yang tidak termasuk dalam model penelitian.

\section{Uji Hipotesis Simultan}

Untuk menguji pengaruh dari variabel kepemimpinan transformasional, komitmen karyawan dan motivasi secara simultan terhadap kepuasan kerja (hipotesis 1).

Pengujian secara simultan pada penelitian ini menggunakan statistik uji $\mathrm{F}$ dengan F-hitung sebesar 133,508 , sedangkan nilai F-tabel $=\mathrm{F}_{[0.05 ;(3,259-3-1)]}=$ 2,600 .

Kriteria penolakan $\mathrm{H}_{0}$ jika $\left(\mathrm{F}_{\text {hitung }}>\mathrm{F}_{\text {tabel }}\right)$. Dari hasil perhitungan di atas, maka $\mathrm{H}_{0}$ ditolak, artinya kepemimpinan transformasional, komitmen karyawan dan motivasi secara simultan berpengaruh signifikan terhadap kepuasan kerja (hipotesis 1 terbukti).

\section{Uji Hipotesis Parsial}

Pengujian parsial dilakukan untuk menguji pengaruh dari variabel kepemimpinan transformasional, komitmen karyawan, dan motivasi secaramasing-masing (parsial) berpengaruh signifikan 
terhadap kepuasan kerja karyawan perusahaan BUMN Industri Pertahanan di Jawa Barat. Pengujian ini dilakukan untuk menguji hipotesis 2, 3, dan 4. Pengujian parsial ini juga dilakukan untuk menguji pengaruh dari variabel kepuasan kerja terhadap kinerja karyawan (hipotesis 5).

Berdasarkan Tabel 29. terbukti bahwa secara parsial dapat disimpulkan kepemimpinan transformasional memiliki pengaruh yang signifikan terhadap kepuasan kerja, dengan demikian hipotesis 2 terbukti. Selanjutnya dapat disimpulkan juga bahwa komitmen karyawan memiliki pengaruh yang signifikan terhadap kepuasan kerja, dengan demikian hipotesis 3 terbukti. Demikian juga dengan variabel motivasi memiliki pengaruh yang signifikan terhadap kepuasan kerja, dengan demikian hipotesis 4 terbukti.

Hasil analisis berdasarkan Tabel 30. membuktikan bahwa secara parsial dapat disimpulkan kepuasan kerja memiliki pengaruh yang signifikan terhadap kinerja karyawan, dengan demikian hipotesis 5 terbukti.

\section{Uji Kelayakan Model Penelitian}

Hasil uji kelayakan model menunjukan bahwa model penelitian telah memenuhi kriteria the goodness of an econometric model atau karakteristik yang dapat diharapkan dan dijabarkan sebagai berikut:

1) Kesesuaian dengan teori(theoretical plausibility). Model penelitian ini memperlihatkan bahwa hasil uji sesuai dengan ekspektasinya dan teori manajemen sumber daya manusia yang menjadi dasar pemikiran (Tabel 31.).
2) Akurasi estimasi parameter (accuracy of the estimates of the parameters). Model penelitian ini menghasilkan estimator koefisien jalur yang akurat atau tidak bias dan signifikan. Asumsi analisis terpenuhi dan probabilitas kesalahan statistik dari model sangat rendah ( $p$-value $<$ $0,05)$. Berdasarkan Tabel 32. dapat disimpulkan bahwa ukuran parameter tersebut memiliki hasil yang akurat.

3) Kemampuan menjelaskan (explanatory ability). Model penelitian ini memiliki kemampuan tinggi dalam menjelaskan hubungan antar variabel penelitian jika Standard Error (SE) $<1 / 2 \gamma$ Koefisien Jalur). Analisis berdasarkan Tabel 33. menunjukkan bahwa hubungan antar variabel tersebut signifikan.

4) Kemampuan Memprediksi (Forecasting Ability). Model penelitian ini memiliki kemampuan prediksi yang tinggi atas perilaku variabel terikat sebagaimana ditunjukan oleh tingginya koefisien determinasi model yang mendekati atau melebihi $50 \%$ dengan perincian sebagai berikut:

a. Pengaruh simultan kepemimpinan transformasional $\left(\mathrm{X}_{1}\right)$, komitmen karyawan $\left(\mathrm{X}_{2}\right)$ dan motivasi $\left(\mathrm{X}_{3}\right)$ terhadap kepuasan kerja (Y) sebesar 61,210\%.

b. Pengaruh kepuasan kerja (Y) terhadap kinerja karyawan $(Z)$ sebesar $68,890 \%$.

Dengan demikian berdasarkan empat kriteria tersebut, maka dapat disimpulkan bahwa model yang disusun telah memenuhi kriteria kelayakan model (the goodness of an econometric) yang dilandasi perspektif teori yang kuat.

Tabel 29. Pengujian Parsial Variabel Kepemimpinan Transformasional ( $\xi 1)$,

Komitmen Karyawan $\left(\xi_{2}\right)$, Motivasi Karyawan $\left(\xi_{3}\right)$, terhadap Kepuasan Kerja ( $\left.\eta 1\right)$

\begin{tabular}{|c|c|c|c|c|c|c|}
\hline Variabel & $\begin{array}{l}\text { Koefisien } \\
\text { Jalur }\end{array}$ & $\mathbf{t}_{\text {hitung }}$ & $\mathbf{t}_{\text {tabel }}$ & $\mathbf{P}_{\text {value }}$ & $\begin{array}{c}\text { Kriteria } \\
\text { Hipotesis }\end{array}$ & Kesimpulan \\
\hline Kepemimpinan Transformasional & 0,287 & 4,073 & 1,965 & 0,000 & $\begin{array}{c}\text { Tolak } \mathrm{H}_{0^{\prime}} \text { jika } \\
\mathrm{t}_{\text {hitung }}>\mathrm{t}_{\text {tabel }}\end{array}$ & $\begin{array}{l}\mathrm{H}_{0} \text { ditolak, terdapat pengaruh signifikan } \\
\text { antara Kepimimpinan Transformasional } \\
\text { terhadap Kepuasan Kerja }\end{array}$ \\
\hline Komitmen Karyawan & 0,228 & 2,115 & 1,965 & 0,034 & $\begin{array}{c}\text { Tolak } \mathrm{H}_{0^{\prime}} \text { jika } \\
\mathrm{t}_{\text {hitung }}>\mathrm{t}_{\text {tabel }}\end{array}$ & $\begin{array}{l}\mathrm{H}_{0} \text { ditolak, terdapat pengaruh } \\
\text { signifikan antara Komitmen Karyawan } \\
\text { terhadap Kepuasan Kerja }\end{array}$ \\
\hline Motivasi Karyawan & 0,451 & 3,691 & 1,965 & 0,000 & $\begin{array}{c}\text { Tolak } \mathrm{H}_{0^{\prime}} \text { jika } \\
\mathrm{t}_{\text {hitung }}>\mathrm{t}_{\text {tabel }}\end{array}$ & $\begin{array}{l}\mathrm{H}_{0} \text { ditolak, terdapat pengaruh } \\
\text { signifikan antara Motivasi terhadap } \\
\text { Kepuasan Kerja }\end{array}$ \\
\hline
\end{tabular}


Tabel 30. Pengujian Parsial Variabel Kepuasan Kerja $\left(\eta_{1}\right)$

terhadap Kinerja Karyawan $\left(\eta_{2}\right)$

\begin{tabular}{cccccl}
\hline Koefisien Jalur & $\mathbf{t}_{\text {hit }}$ & $\mathbf{t}_{\text {tab }}$ & $\mathbf{P}_{\text {value }}$ & Kriteria hipotesis & Kesimpulan \\
\hline 0,826 & 6,317 & 1,965 & 0,000 & $\begin{array}{c}\text { Tolak } \mathrm{H}_{0^{\prime}} \\
\text { jika } \mathrm{t}_{\text {hitung }}>\mathrm{t}_{\text {tabel }}\end{array}$ & $\begin{array}{l}\mathrm{H}_{0} \text { ditolak, terdapat pengaruh signifikan antara } \\
\text { Kepuasan Kerja terhadap Kinerja Karyawan }\end{array}$ \\
\hline
\end{tabular}

Sumber: Data primer, diolah, 2013.

Tabel 31. Hasil Uji Kesesuaian Teori

\begin{tabular}{lccc}
\multicolumn{1}{c}{ Hubungan Antar Variabel } & Pra Estimasi & Pasca Estimasi & Kesesuaian \\
\hline $\begin{array}{l}\text { Kepemimpinan transformasional, komitmen karyawan, dan motivasi secara } \\
\text { simultan dan parsial berpengaruh signifikan terhadap kepuasan kerja } \\
\text { karyawan perusahaan BUMN Industri Pertahanan di Jawa Barat }\end{array}$ & + & + \\
$\begin{array}{l}\text { Kepuasan kerja berpengaruh signifikan terhadap kinerja karyawan } \\
\text { perusahaan BUMN Industri Pertahanan di Jawa Barat }\end{array}$ & + & Sesuai \\
\hline
\end{tabular}

Sumber: Data primer, diolah, 2013.

Tabel 32. Akurasi Estimasi Parameter

\begin{tabular}{lccc}
\hline \multicolumn{1}{c}{ Variabel } & Koefisien Jalur & $\mathbf{P}_{\text {value }}$ & Hasil \\
\hline Kepemimpinan Transformasional & 0,287 & 0,000 & Akurat \\
Komitmen Karyawan & 0,228 & 0,034 & Akurat \\
Motivasi & 0,451 & 0,000 & Akurat \\
Kepuasan Kerja & 0,826 & 0,000 & Akurat \\
\hline
\end{tabular}

Sumber: Data primer, diolah, 2013.

Tabel 33. Explanatory Ability

\begin{tabular}{lccc}
\hline \multicolumn{1}{c}{ Variabel } & Stand. Error & Koefisien Jalur & Hasil \\
\hline Kepemimpinan transformasional terhadap kepuasan kerja & 0,055 & 0,287 & $0,055<1 / 2(0,287)$ Signifikan \\
Komitmen karyawan terhadap kepuasan kerja & 0,106 & 0,228 & $0,106<1 / 2(0,228)$ Signifikan \\
Motivasi terhadap kepuasan kerja & 0,101 & 0,451 & $0,101<1 / 2(0,451)$ Signifikan \\
Kepuasan kerja terhadap kinerja karyawan & 0,098 & 0,826 & $0,098<1 / 2(0,826)$ Signifikan \\
\hline
\end{tabular}

\section{PEMBAHASAN}

Deskripsi Variabel Kepemimpinan Transformasional

Hasil analisis deskriptif terhadap variabel kepemimpinan transformasional yang terkait dengan dimensi pengaruh ideal, motivasi inspirasional, stimulasi intelektual dan perhatian individu didapat hasil nilai rata-rata sebesar 3,780 dan nilai standar deviasi sebesar 0,839. Nilai jawaban tersebut mengindikasikan bahwa responden mempersepsikan kepemimpinan transformasional yang dilaksanakan para pimpinan di perusahaan BUMNIP Jawa Barat dalam kategori kuat. Namun secara keseluruhan maka nilai jawaban responden berada pada kisaran 2,941 sampai dengan 4,619, sehingga mengindikasikan kepemimpinan transformasional berada pada rentang cukup kuat sampai dengan sangat kuat.

Berdasarkan hasil jawaban responden terhadap variabel kepemimpinan transformasional didapatkan temuan tentang kontribusi dimensi dimana dimensi pengaruh ideal memiliki nilai rata-rata tertinggi yaitu 3,877. Namun pada sisi lain, dimensi perhatian 
individu merupakan dimensi terendah karena memiliki nilai rata-rata 3,686.

Oleh karena itu, hasil empiris tersebut dapat menjadi bahan pertimbangan dan saran-saran bagi pimpinan dalam rangka meningkatkan peran kepemimpinan transformasional di perusahaan khususnya pada dimensi perhatian individu dengan indikator perhatian pimpinan terhadap karyawan yang berprestasi dan komunikasi pimpinan dengan karyawan.

\section{Deskripsi Variabel Komitmen Karyawan}

Hasil analisis deskriptif terhadap variabel komitmen karyawan yang terdiri dari dimensi komitmen afektif, komitmen berkelanjutan, dan komitmen normatif didapat hasil nilai rata-rata sebesar 3,857 dan nilai standar deviasi sebesar 0,799. Nilai jawaban tersebut mengindikasikan bahwa responden mempersepsikan komitmen karyawan pada perusahaan BUMNIP Jawa Barat dalam kategori tinggi. Namun secara keseluruhan maka nilai jawaban responden berada pada kisaran 3,058 sampai dengan 4,656, sehingga mengindikasikan komitmen karyawan berada pada rentang cukup tinggi sampai dengan sangat tinggi.

Berdasarkan hasil jawaban responden terhadap variabel komitmen karyawan didapatkan temuan tentang kontribusi dimensi dimana dimensi komitmen normatif memiliki nilai rata-rata tertinggi yaitu 3,941. Namun demikian disisi lain, dimensi komitmen berkelanjutan merupakan dimensi terendah karena memiliki nilai rata-rata sebesar 3,761.

Oleh karena itu, hasil empiris dari penelitian ini menjadi bahan pertimbangan dan saran bagi manajemen perusahaan dalam rangka meningkatkan komitmen karyawan, khususnya pada dimensi komitmen berkelanjutan dengan indikator keinginan karyawan untuk pindah ke perusahaan lain dan perasaan karyawan yang tidak merasa rugi jika meninggalkan perusahaan.

\section{Deskripsi Variabel Motivasi}

Hasil analisis deskriptif terhadap variabel motivasi yang terdiri dari dimensi keinginan untuk berprestasi, keinginan untuk berafiliasi, dan keinginan untuk kekuasaan didapat hasil nilai rata-rata sebesar 3,874 dan nilai standar deviasi sebesar 0,770 . Nilai jawaban tersebut mengindikasikan bahwa responden mempersepsikan motivasi karyawan pada perusahaan
BUMNIP Jawa Barat dalam kategori tinggi. Namun secara keseluruhan maka nilai jawaban responden berada pada kisaran 3,104 sampai dengan 4,644, sehingga mengindikasikan motivasi karyawan berada pada rentang cukup tinggi sampai dengan sangat tinggi.

Berdasarkan hasil jawaban responden terhadap variabel motivasi didapatkan temuan tentang kontribusi dimensi dimana dimensi kebutuhan untuk berprestasi memiliki nilai rata-rata tertinggi yaitu 4,073. Namun demikian disisi lain, dimensi kebutuhan untuk kekuasaan merupakan dimensi yang terendah karena memiliki nilai rata-rata sebesar 3,509..

Maka hasil empiris tersebut dapat dijadikan bahan pertimbangan dan saran bagi manajemen perusahaan dalam membuat suatu kebijakan yang dapat meningkatkan motivasi karyawan, khususnya pada dimensi kebutuhan untuk kekuasaan dengan indikator kemampuan aktualisasi diri karyawan dalam bidang pekerjaannya dan menumbuhkan keinginan karyawan untuk mengarahkan dan mengendalikan karyawan lain.

\section{Deskripsi Variabel Kepuasan Kerja}

Hasil analisis deskriptif terhadap variabel kepuasan kerja yang terdiri dari dimensi faktor psikologi, faktor finansial, faktor fisik dan faktor sosial didapat hasil nilai rata-rata sebesar 3,632 dan nilai standar deviasi sebesar 0,863 . Nilai jawaban tersebut mengindikasikan bahwa responden mempersepsikan kepuasan kerja karyawan pada perusahaan BUMNIP Jawa Barat dalam kategori puas. Namun secara keseluruhan maka nilai jawaban responden berada pada kisaran 2,690 sampai dengan 4,495, sehingga mengindikasikan kepuasan kerja karyawan berada pada rentang cukup puas sampai dengan sangat puas.

Berdasarkan hasil jawaban responden terhadap variabel kepuasan kerja didapatkan temuan tentang kontribusi dimensi dimana dimensi faktor psikologi memiliki nilai rata-rata tertinggi yaitu 3,858. Namun demikian disisi lain, faktor finansial merupakan dimensi yang terendah karena memiliki nilai rata-rata sebesar 3,354.

Oleh karena itu, hasil empiris ini menjadi bahan pertimbangan dan saran bagi manajemen perusahaan dalam rangka meningkatkan kepuasan kerja karyawan khususnya pada dimensi faktor finansial dengan indikator memperbaiki kondisi gaji karyawan serta kebijakan bonus yang diterima oleh karyawan. 


\section{Deskripsi Variabel Kinerja Karyawan}

Hasil analisis deskriptif terhadap variabel kinerja karyawan yang terdiri dari dimensi kemampuan, efektifitas dan efisiensi, otoritas, disiplin dan inisiatif didapat hasil nilai rata-rata sebesar 4,036 dan nilai standar deviasi sebesar 0,659. Nilai jawaban tersebut mengindikasikan bahwa responden mempersepsikan kinerja karyawan pada perusahaan BUMNIP Jawa Barat dalam kategori tinggi. Namun secara keseluruhan maka nilai jawaban responden berada pada kisaran 3,377 sampai dengan 4,695, sehingga mengindikasikan kinerja karyawan berada pada rentang cukup tinggi sampai dengan sangat tinggi.

Berdasarkan hasil jawaban responden terhadap variabel kinerja karyawan didapatkan temuan tentang kontribusi dimensi dimana dimensi kemampuan memiliki nilai rata-rata tertinggi yaitu 4,101. Namun demikian disisi lain, faktor disiplin merupakan dimensi yang terendah karena memiliki nilai rata-rata sebesar 3,980.

Oleh karena itu, hasil empiris dari penelitian ini menjadi bahan pertimbangan dan saran-saran bagi manajemen perusahaan dalam rangka meningkatkan kinerja karyawan, khususnya pada dimensi disiplin dengan indikator penyelesaian tugas sesuai waktu yang ditetapkan dan keberanian karyawan dalam menghadapi resiko pekerjaan.

\section{Pembahasan Pengaruh Kepemimpinan Transformasional, Komitmen Karyawan, dan Motivasi secara Simultan terhadap Kepuasan Kerja}

Kepemimpinan transformasional, komitmen karyawan dan motivasi secara simultan memiliki pengaruh yang cukup signifikan terhadap kepuasan kerja karyawan pada perusahaan BUMN Industri Pertahanan di Jawa Barat. Total kontribusi yang diberikan oleh kepemimpinan transformasional, komitmen karyawan dan motivasi terhadap kepuasan kerja sebesar $61,210 \%$. Makna dari pengujian statistik tersebut menyatakan bahwa kepemimpinan transformasional, komitmen karyawan dan motivasi memiliki peranan sebesar $61,210 \%$ dalam mendukung peningkatan kepuasan kerja, sedangkan $38,790 \%$ dipengaruhi oleh variabel lain. Turun dan naiknya kepuasan kerja karyawan pada perusahaan BUMN Industri Pertahanan di Jawa Barat salah satunya ditentukan oleh faktor kepemimpinan transformasional, komitmen karyawan dan motivasi.

Hasil penelitian ini membuktikan kebenaran pernyataan teoritik dari Parry (2004), Viator (2001),
Pillai dan Williams (2004), bahwa pemimpin dengan gaya kepemimpinan transformasional dan komitmen karyawan pada organisasi akan mempengaruhi dan membangun anggota kelompok secara individu untuk mencapai potensi yang lebih tinggi sehingga dapat memberikan semangat bawahannya untuk berfikir secara kritis dan menciptakan gairah kerja. Semangat berfikir kritis dan menciptakan gairah kerja merupakan cerminan dari kepuasan kerja karyawan.

Oleh karena itu, hasil empiris tersebut dapat menjadi bahan pertimbangan dan saran-saran bagi pimpinan dalam rangka meningkatkan kepuasan kerja karyawan dengan memperhatikan aspek kolaboratif dari variabel kepemimpinan transformasional, komitmen karyawan dan motivasi.

Hasil penelitian ini sesuai dengan beberapa penelitian lain, seperti hasil penelitian yang dilakukan oleh Barbuto (2005) menunjukkan bahwa kepemimpinan transformasional mempunyai hubungan positif dengan motivasi. Hasil penelitian lainnya dari Fred O. Walumba et al. (2008) yang menyatakan bahwa kepemimpinan transformasional berhubungan positif dengan komitmen karyawan.

\section{Pembahasan Pengaruh Kepemimpinan Transformasional terhadap Kepuasan Kerja}

Kepemimpinan transformasional secara parsial memiliki pengaruh yang cukup signifikan terhadap kepuasan kerja karyawan pada perusahaan BUMNIP di Jawa Barat. Total kontribusi yang diberikan oleh kepemimpinan transformasional terhadap kepuasan kerja sebesar $15,060 \%$. Makna dari pengujian statistik tersebut dinyatakan bahwa kepemimpinan transformasional memiliki peranan dalam mendukung terhadap peningkatan kepuasan kerja.

Hasil penelitian ini membuktikan kebenaran pernyataan teoritik dari Pawar dan Eastman (1997) yang menyatakan bahwa praktik gaya kepemimpinan transformasional mampu membawa perubahanperubahan yang lebih mendasar seperti nilai-nilai, tujuan, dan kebutuhan karyawan serta perubahanperubahan tersebut berdampak pada meningkatnya kepuasan kerja karyawan karena terpenuhinya kebutuhan yang lebih tinggi. Hasil temuan penelitian ini memperkuat hasil penelitian dari Risambessy et al. (2011), Irwansyah (2011), Judge and Locke (1993), yang membuktikan secara empiris bahwa terdapat pengaruh signifikan kepemimpinan transformasional terhadap kepuasan kerja. Pendapat lain dari Stone et.al (2004), kepemimpinan transformasional 
sebagai pengaruh pemimpin terhadap bawahan. Bawahan merasa adanya kepercayaan, kebanggaan, loyalitas dan rasa hormat kepada atasan serta mereka termotivasi untuk melakukan melebihi apa yang diharapkan. Kepemimpinan transformasional harus dapat mengartikan dengan jelas visi untuk organisasi, sehingga pengikutnya menerima kredibilitas pemimpin.

Oleh karena itu, hasil empiris tersebut dapat menjadi bahan pertimbangan dan saran-saran bagi pimpinan dalam rangka meningkatkan kepuasan kerja karyawan maka perlu untuk memperhatikan dimensi -dimensi dalam kepemimpinan transformasional yaitu dimensi pengaruh ideal, motivasi inspirasional, stimulasi intelektual dan perhatian individu.

\section{Pembahasan Pengaruh Komitmen Karyawan terhadap Kepuasan Kerja}

Komitmen karyawan secara parsial memiliki pengaruh yang cukup signifikan terhadap kepuasan kerja karyawan pada perusahaan BUMN industri pertahanan di Jawa Barat. Total kontribusi yang diberikan oleh komitmen karyawan terhadap kepuasan kerja sebesar 14,960\%. Makna dari pengujian statistik tersebut dinyatakan bahwa komitmen karyawan memiliki peranan dalam mendukung terhadap peningkatan kepuasan kerja.

Hasil penelitian ini mendukung kebenaran penelitian dari Djati dan Khusaini (2003) bahwa komitmen karyawan bukan hanya kesetiaan pada organisasi, tetapi suatu proses yang berjalan dimana karyawan mengekspresikan kepeduliannya terhadap organisasi dengan prestasi kerja yang tinggi. Hasil penelitian ini sesuai dengan penelitian Aranya et al. (1982), Cahyono dan Gozali (2002) yang menyatakan bahwa para karyawan yang memiliki loyalitas pada organisasinya cenderung akan merasa puas dalam pekerjaannya (job stisfaction).

Oleh karena itu, hasil empiris tersebut dapat menjadi bahan pertimbangan dan saran-saran bagi pimpinan dalam rangka meningkatkan kepuasan kerja karyawan maka perlu untuk memperhatikan dimensi -dimensi dalam komitmen karyawan yaitu dimensi komitmen normatif, afektif dan komitmen berkelanjutan.

\section{Pembahasan Pengaruh Motivasi terhadap Kepuasan Kerja}

Motivasi secara parsial memiliki pengaruh yang cukup signifikan terhadap kepuasan kerja karyawan pada perusahaan BUMNIP di Jawa Barat. Total kontribusi yang diberikan oleh motivasi terhadap kepuasan kerja sebesar 31,190\%. Makna dari pengujian statistik tersebut dinyatakan bahwa motivasi memiliki peranan dalam mendukung terhadap peningkatan kepuasan kerja. Turun dan naiknya kepuasan kerja karyawan pada perusahaan BUMN industri pertahanan di Jawa Barat salah satunya ditentukan oleh faktor motivasi yang terdiri dari kebutuhan berprestasi, kebutuhan berafiliasi dan kebutuhan kekuasaan.

Hasil penelitian ini sesuai dengan hasil penelitian Kehinde (2011) bahwa para pekerja yang kurang termotivasi dalam bekerja maka mereka akan memulai reaksinya dengan tindakan-tindakan ringan, seperti datang terlambat sebelum beralih ke tindakan yang lebih berat yaitu absen dan pada akhirnya keluar dari perusahaan. Hal ini dikarenakan karyawan tersebut merasakan ketidakpuasan dengan kebijakan perusahaan maupun tidak puas terhadap pekerjaannya. Hasil penelitian ini mendukung pernyataan hasil penelitian Smith et al. (2004), Tella et al. (2007), dan Furnham et al. (2009), bahwa motivasi karyawan berpengaruh positif terhadap kepuasan kerja.

Oleh karena itu, hasil empiris tersebut dapat menjadi bahan pertimbangan dan saran-saran bagi pimpinan dalam rangka meningkatkan kepuasan kerja karyawan maka perlu untuk memperhatikan dimensidimensi motivasi karyawan yaitu dimensi kebutuhan berprestasi, kebutuhan berafiliasi dan kebutuhan berkuasa.

\section{Pembahasan Pengaruh Kepuasan Kerja Terhadap Kinerja Karyawan}

Kepuasan kerja secara parsial memiliki pengaruh yang signifikan terhadap kinerja karyawan pada perusahaan BUMN Industri Pertahanan di Jawa Barat. Total kontribusi yang diberikan oleh kepuasan kerja terhadap kinerja karyawan sebesar $68,890 \%$, sedangkan sisanya $31,110 \%$ dipengaruhi oleh variabel lain di luar model penelitian. Makna dari pengujian statistik tersebut dinyatakan bahwa kepuasan kerja memiliki peranan dalam mendukung terhadap peningkatan kinerja karyawan.

Hasil penelitian ini membuktikan kebenaran pernyataan teoritik dari Dessler (2003) yang menyatakan bahwa kepuasan kerja mempunyai peran untuk mencapai produktivitas dan kualitas standar yang lebih baik dan penggunaan sumber daya manusia yang lebih efisien. Hasil penelitian 
ini mendukung pernyataan dari Soumendu Biswas dan Arup Varma (2007), Ostrof (1992), Laschinger, Finegen dan Shamian (2001) serta Surya dan Haedar (2004), bahwa kepuasan kerja berpengaruh positif signifikan terhadap kinerja karyawan.

Oleh karena itu, hasil empiris tersebut dapat menjadi bahan pertimbangan dan saran-saran bagi pimpinan dalam rangka meningkatkan kinerja karyawan maka perlu untuk memperhatikan dimensidimensi dalam kepuasan kerja karyawan yaitu dimensi faktor psikologi, finansial, fisik, dan sosial.

\section{KESIMPULAN}

Kepemimpinan transformasional di perusahaan BUMN Industri Pertahanan di Jawa Barat dipersepsikan cukup kuat sampai dengan sangat kuat. Nilai rata-rata tertinggi terdapat pada dimensi pengaruh ideal, sedangkan pada sisi lain dimensi perhatian individu memiliki nilai rata-rata terendah. Hal ini berarti pemimpin di perusahaan BUMN Industri Pertahanan Jawa Barat memiliki visi, misi, dan program yang jelas serta memiliki integritas, sedangkan pada sisi lain pemimpin di perusahaan BUMN Industri Pertahanan Jawa Barat kurang melakukan komunikasi dengan karyawan dan kurang memperhatikan karyawan yang berprestasi.

Komitmen karyawan di perusahaan BUMN Industri Pertahanan di Jawa Barat dipersepsikan cukup tinggi sampai dengan sangat tinggi. Nilai rata-rata tertinggi terdapat pada dimensi komitmen normatif, sedangkan pada sisi lain dimensi komitmen berkelanjutan memiliki nilai rata-rata terendah. Hal ini berarti mayoritas karyawan mau menerima tugas dan memiliki niat untuk tetap bekerja di perusahaan, sedangkan dilain pihak ada sebagian karyawan yang tidak merasa rugi jika meninggalkan perusahaan dan mudah untuk mencari ganti perusahaan.

Motivasi karyawan perusahaan BUMN Industri Perusahaan BUMN Industri Pertahanan di Jawa Barat dipersepsikan dari cukup tinggi sampai dengan sangat tinggi. Nilai rata-rata tertinggi terdapat pada dimensi kebutuhan untuk berprestasi, sedangkan pada sisi lain dimensi kebutuhan untuk berkuasa memiliki nilai rata-rata terendah. Hal ini berarti mayoritas karyawan ingin berusaha untuk mencapai prestasi yang lebih baik, melakukan pekerjaan lebih baik daripada sebelumnya dan ingin meningkatkan pengetahuan dan ketrampilan, sedangkan pada sisi lain ada sebagian karyawan yang kurang melalukan aktualisasi diri, kurang peduli dalam mengarahkan dan mengendalikan karyawan lain serta kurang memiliki karakter sebagai pemimpin.

Kepuasan kerja karyawan perusahaan BUMN Industri Pertahanan di Jawa Barat dipersepsikan dari cukup puas sampai dengan sangat puas. Nilai ratarata tertinggi terdapat pada dimensi faktor psikologi, sedangkan pada sisi lain dimensi faktor finansial memiliki nilai rata-rata terendah. Hal ini berarti mayoritas karyawan memiliki sikap dan perilaku positif dalam bekerja dan memiliki rasa suka terhadap pekerjaan, sedangkan pada sisi lain ada sebagian karyawan yang kurang puas terhadap pemberian bonus dari perusahaan dan kurang puas terhadap besaran gaji yang diterima.

Kinerja karyawan perusahaan BUMN Industri Pertahanan di Jawa Barat dipersepsikan dari cukup tinggi sampai dengan sangat tinggi. Nilai ratarata tertinggi terdapat pada dimensi kemampuan, sedangkan pada sisi lain dimensi disiplin memilikinilai rata-rata terendah. Hal ini berarti mayoritas karyawan memiliki kecakapan kerja sesuai standar perusahaan dan memiliki kemampuan untuk bekerjasama dengan karyawan lain, sedangkan pada sisi lain ada sebagian karyawan belum mentaati waktu yang telah ditetapkan dalam menyelesaikan tugas dan bersedia menerima sanksi dari perusahaan sesuai dengan kesalahan.

Kepemimpinan transformasional, komitmen karyawan dan motivasi secara simultan berpengaruh positif dan signifikan terhadap kepuasan kerja karyawan perusahaan BUMN Industri Pertahanan di Jawa Barat. Motivasi mempunyai pengaruh paling besar terhadap kepuasan karyawan bila dibandingkan dengan kepemimpinan transformasional dan komitmen karyawan. Semakin tinggi penilaian karyawan terhadap variabel kepemimpinan transformasional, komitmen karyawan dan motivasi secara kolaboratif, maka semakin besar pengaruhnya dalam meningkatkan kepuasan kerja karyawan.

Kepemimpinan transformasional, komitmen karyawan, motivasi secara parsial berpengaruh positif dan signifikan terhadap kepuasan kerja karyawan perusahaan BUMN Industri Pertahanan di Jawa Barat pengaruh baik secara langsung maupun tidak langsung. Berdasarkan hal tersbut maka dapat disimpulkan bahwa semakin tinggi penilaian karyawan terhadap variabel kepemimpinan transformasional, maka semakin besar pengaruhnya dalam meningkatkan kepuasan kerja karyawan. Selain itu semakin tinggi penilaian karyawan terhadap 
variabel komitmen karyawan, maka semakin besar pengaruhnya dalam meningkatkan kepuasan kerja karyawan. Kesimpulan lainnya adalah semakin tinggi penilaian karyawan terhadap variabel motivasi, maka semakin besar pengaruhnya dalam meningkatkan kepuasan karyawan. Terakhir adalah kesimpulan bahwa kepuasan kerja berpengaruh positif dan signifikan terhadap kinerja karyawan perusahaan BUMN Industri Pertahanan di Jawa Barat. Dengan demikian semakin tinggi kepuasan kerja yang dirasakan karyawan maka kinerja karyawan semakin meningkat.

\section{DAFTAR PUSTAKA}

Allen, N. J., Meyer P. J. \& Smith C. A. 1999. Commitment to Organizations and Occupations: Extention and Test of a Three-Component Conceptualization. Journal of Applied Psychology, 78(4).

Aranya, N., R. Lachman \& J. Amernic. 1982. Accountants'Job Satisfaction: A Path Analysis. Accounting, Organizations and Society, 7(3): 201-215.

Avolio,B. J. \& Bersona, Y. 2004. Transformational Leadership and the $\mathrm{D}$ issemination of Organizatioanl Goals: A Case Study of A Telecomunication Firm. Leadership Quarterly Journal, 15: 625-646.

Barbuto, J. E. 2005. Taking The Charisma Out of Transformational Leadership. Journal of Social Behavior and Personality, 12: 689-697.

Bass, B. M. 1997. Does Transactional Transformational Leadership Paradigm Transcend Organizational and National Boundaries?. Journal American Psychologist, 52: 130-139.

Cahyono, Dwi \& Gozali, Imam. 2002. Pengaruh Jabatan, Budaya Organisasional dan Konflik Peran terhadap Hubungan Kepuasan Kerja dengan Komitmen Organisasi: Studi Empiris di Kantor Akuntan Publik. JRAI, 5(3).

Dharma, Surya \& Haedar, Akib. 2004. Budaya Organisasi Kreatif. Manajemen USAHAWAN Indonesia XXXIII (Maret): 22-27.

Dessler, Gary. 2003. Human Resource Management. Tenth Edition. New Jersey: Prentice Hall.

Farrell, Dan and James C. 1984. Petersen. Commitment, Absenteeism and Turnover of New Employees. Human Relations, 37 (August): 681692.
Ferdinand, A. 2005. Structural Equation Modeling dalam Penelitian Manajemen (Edisi 2). Semarang: Badan Penerbit Undip.

Furnham, Adrian, Andreas Eracleous, Tomas Chamorro-Premuzic. 2009. Personality, Motivation and Job Satisfaction: Hertzberg Meets the Big Five. Journal of Managerial Psychology, 24(8): 765 - 779 .

Hackett, R. D. and Guion, R. M. (1985). A Re-evaluation of the Absenteeism - Job Satisfaction Relationship. Organizational Behaviour and Human Decision Processes. Organizational Behaviour and Human Performance, 35, 340-381.

Hair, J. F. Anderson, R. F. Totham, R. L. \& Black, W. C. 1998. Multivariate Data Analysis (th edition). New Jersey: Prentice Hall.

Jones, G. R., \& George, J. M. 2003. Contemporary Management $\left(3^{\text {th }}\right.$ Edition). New York: McGraw Hill Inc.

Judge, T. A., \& Locke, E. A. 1993. Effect of Dysfunctional Thought Processeson Subjective Well-Being and Job Satisfaction. Journal of Applied Psychology,78 (3): 475-490.

Kehinde, Obasan., A., 2011. Impact of Job Satisfaction on Absenteeism: A Correlative Study. European Journal of Humanities and Social Sciences, 1(1).

Laschinger, H. K. S., Finegan, J., \& Shamian, J. 2001. The Impact of Workplace Empowerment and Organizational Trust on Staff Nurses' Work Satisfaction and Organizational Commitment. Health Care Management Review, 26(3), 7-23.

Locke, Edwin A. \& Garry, P. Latham. 2002. Building a Practically Useful Theory of Goal Setting and Task Motivation. American Psychologis, 7.

Mathis, R. L., \& Jackson J. H., 2008. Manajemen Sumber Daya Manusia (Edisi 10). Jakarta: Salemba Empat.

Meyer, John P. \& Allen N. J. 2007. Commitment in the Worldplace Theory Research and Application. California: Sage Publications.

Morrison, R. L. 2008. Negative relationships in the workplace: Associations with Organizational Commitment, Cohesion, Job Satisfaction and Intention to Turnover. Journal of Management and Organization, 14(4), 330-344.

Ostroff, C. 2003. The Relationship between Satisfaction, Attitudes, and Performance: An Organizational Level Analysis. Journal of Applied Psychology, 77: 963. 
Pantja, Djati \& Khusaini, M. K. 2003. Kajian Terhadap Kepuasan Kompensasi, Komitmen Organisasi, dan Prestasi Kerja. Jurnal Manajemen Kewirausahaan, 5(1).

Parry, K. W. 2004. Comparative Modelling of The Social Processes of Leadership in Work Units. Journal of Management \& Organization, 10(2), 69-80.

Pawar, B. S. \& Eastman, K. K. 1997. The Nature and Implications of Contextual Influences on Transformational Leadership: A Conceptual Examination. Academy of Management Review, 22: 80-109.

Pillai, R. \& Williams, E. A. 2004. Transformational Leadership, Veness, Commitment, and Performance. Journal of Organizational Change Management, 17(2), 144-159.

Risambessy, A., Swasto, B., Thoyib, A., \& Astuti, E. S. 2012. The Influence of Transformational Leadership Style, Motivation, Burnout Towards Job Satisfaction and Employee Performance. Journal of Basic and Applied, 2(9): 8833-8842.

Robbins, S. P. \& Judge, T. A. 2009. Organisational Behaviour (13 ${ }^{\text {th }}$ edition). Prentice Hall.

Saydam, Gouzali. 2005. Manajemen Sumber Daya Manusia (Cetakan Pertama). Jakarta: Gunung Agung.
Smith, B. N., Montagno, R. V., \& Kuzmenko, T. N. 2004. Transformational and Servant Leadership: Content and Contextual Comparisons. Journal of Leadership and Organizational Studies, 10(4), 80-91.

Stone, G. A., Russel, R. F., \& Patterson, K. 2004. Transformational Versus Servant Leadership: A Difference in Leader Focus. The Leadership \& Organization Development Journal, 25(4).

Soumendu Biswas \&Arup Varma. 2007. Psychological Climate and Individual Performance in India: Test of A Mediated Model. Employeeee Relations, 29(6): $664-676$.

Tella, Adeyinka. 2007. Work Motivation, Job Satisfaction, and Organisational Commitment of Library Personnel in Academic and Research Libraries in Oyo State. Nigeria Library Philosophy and Practice.

Truckenbrodt, Y. B. 2000. Leader-Member Exchange and Commitment and Organizational Citizenship Behavior. Acquisition Review Quarterly, (Summer).

Viator, Ralph, E. 2001. The Relevance of Transformational Leadership to Nontraditional Accounting Services: Information Systems Assurance and Business Consulting. Journal of Information Systems, 15(2): 99-125.

Wirasasmita, Y. 2009. Uji kelayakan Model: Extended Handout Metode Penelitian Ekonomi dan Bisnis. Bandung: Unpad. 